\title{
Factors and processes affecting plant biodiversity in permanent grasslands. A review
}

\author{
Etienne Gaujour • Bernard Amiaud • \\ Catherine Mignolet • Sylvain Plantureux
}

Accepted: 20 October 2010 /Published online: 22 March 2011

(C) INRA and Springer Science+Business Media B.V. 2011

\begin{abstract}
Research has delivered convincing findings on the effect of biodiversity on ecosystem functioning and humankind. Indeed, ecosystems provide provisioning, regulating, supporting, and cultural services. The global value of annual ecosystem services of grasslands and rangelands is about US\$ $232 \mathrm{ha}^{-1}$ year $^{-1}$. Nevertheless, the precise evaluation of biodiversity benefits remains challenging. This issue is due to valuation methods, subjective assumptions, and complexity of drivers of plant community dynamics. Here, we review the primary factors that influence plant diversity of permanent grasslands, and we describe underlying processes. These factors must indeed be identified to focus policies meant to preserve and restore plant diversity and to advise farmers about efficient decision rules. We show that plant dynamics of permanent grasslands cannot be explained simply by agricultural management rules, e.g., grazing, fertilization, and mowing, implemented at the field scale. The configuration of the surrounding landscape, e.g., landscape heterogeneity, habitat fragmentation, and connectivity, acts as a species filter that defines the regional species pool and controls seed flow. The regional species pool often contains higher species richness in a heterogeneous landscape, because of a higher diversity of suitable habitats. This
\end{abstract}

\footnotetext{
E. Gaujour $\cdot$ C. Mignolet INRA, UR55 ASTER Mirecourt, 662 avenue Louis Buffet, 88500 Mirecourt, France

B. Amiaud $(\bowtie) \cdot$ S. Plantureux UMR Nancy-Université-INRA Agronomie et Environnement Nancy-Colmar, 2 avenue de la Forêt de Haye, 54505 Vandoeuvre-lès-Nancy, France e-mail: Bernard.Amiaud@ensaia.inpl-nancy.fr
}

regional pool could be a major species sources for permanent grasslands according to the seed flow. We discuss the need to consider all of these factors to understand plant species composition of permanent grasslands and the necessity to study plant communities using both taxonomic and functional approaches. In order to report this integrative approach, we propose a conceptual model based on three ecological challengesdispersal, establishment, and persistence - that are considered to act as filters on plant diversity, and a graphical representation of the complexity of such studies due to the interaction effects between plant dispersal abilities, forage productivity, disturbances induced by farming practices, and landscape heterogeneity on plant diversity. Last, we discuss the ability of farmers to manage each factor and the necessity of such study in the improvement of the current agro-environment schemes efficiency for farmland biodiversity restoration or preservation.

Keywords Agro-environment schemes · Community assembly rules $\cdot$ Ecological filtering $\cdot$ Farmland biodiversity - Farming practices $\cdot$ Landscape pattern . Plant community Plant functional traits $\cdot$ Seed bank

\section{Contents}

1. Introduction $\ldots \ldots \ldots \ldots \ldots \ldots \ldots \ldots \ldots \ldots \ldots \ldots \ldots$

2. Assessable factors at the field scale . ......... 3

2.1. Grazing . . . . . . . . . . . . 3

2.1.1. Stocking rate . . . . . . . . . . 3

2.1.2. Grazing seasonality ..........6 6

2.1.3. Herbivorous livestock . . . . . . . . . . 7

2.2. Nutrient fertilization $\ldots \ldots \ldots \ldots \ldots \ldots 7$ 
2.2.1. Inorganic nutrient fertilization $\ldots \ldots \ldots \ldots 7$

Nitrogen . . . . . . . . . . . 7

Phosphorous ............. 8

Lime . . . . . . . . . . . . . . 8

2.2.2. Organic nutrient fertilization . . . . . . . 8 8

2.3. Mowing ..................9

2.4. Soil seed bank . . . . . . . . . . . . . . . 11

3. Assessable factors at the landscape scale ....... 12

3.1. Landscape heterogeneity . . . . . . . . . . . 13

3.1.1. Definition and primary effects on plant species in farmlands . . . . . . . . . 13

3.1.2. Effects and processes of landscape heterogeneity . . . . . . . . . . . . . . . . . . . 13

3.1.3. Landscape elements . . . . . . . . . . . . 14

3.2. Habitat fragmentation . . . . . . . . . . . . 14

3.2.1. Fragment area .............. 15

3.2.2. Edge effect .............. 16

3.3. Habitat connectivity and corridors ........ 16

3.3.1. Functional connectivity . . . . . . . . 17

3.3.2. Corridors ................. 17

4. Synthesis and conclusion ............ 18

4.1. Knowledge integration in community assembly theory . . . . . . . . . . . . . 18

4.2. Mobilization of factors by a single farmer . . . 20

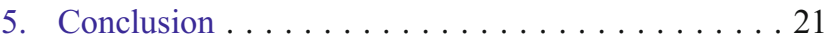

6. Acknowledgments . . . . . . . . . . . . . 22

7. References .................... 22

\section{Introduction}

The Millenium Ecosystem Assessment (Reid et al. 2005) has clearly identified that ecosystem biodiversity preservation is essential for humankind because it provides provisioning, regulating, supporting, and cultural services. Recent biodiversity and ecosystem functioning research has delivered persuasive findings on the effect of biodiversity on ecosystem functioning (Loreau et al. 2001), especially in grassland ecosystems (Hector et al. 2010). For the entire biosphere, the value (most of which is outside the market) is estimated to be in a range of US\$ 16-54 trillion per year, with an average of US\$ 33 trillion per year (Costanza et al. 1997). For example, the global value of annual ecosystem services of grasslands and rangelands has been estimated to US\$ $232 \mathrm{ha}^{-1}$ year $^{-1}$, and the nutrient cycling or pollination ensured by the different biomes have been estimated to US\$ 17 and 117 trillons year ${ }^{-1}$ respectively (Costanza et al. 1997). Nevertheless, the precise and complete evaluation of the benefits from biodiversity still remains difficult, partly because of the valuation methods and some subjective assumptions (Chee 2004; Spangenberg and Settele 2010).

Permanent grasslands are kind of agricultural fields with high biodiversity in farmlands due to high plant species diversity (Gibon 2005; Reidsma et al. 2006). The plant diversity in permanent grasslands potentially provides many benefits for ecosystem functioning and agricultural production: increased forage production (Fischer et al. 2008; Roscher et al. 2005; Tilman et al. 2001; Tilman et al. 1996), greater ecosystem stability in response to biotic and abiotic disturbances (Fischer et al. 2008; Tilman and Downing 1994), decreased invasion by exotic weed species and indigenous species from surrounding habitats (Fischer et al. 2008; Roscher et al. 2009; Sanderson et al. 2007), and enhanced nutrient cycling (Fischer et al. 2008). Plant diversity is thus a key element in both ecological and agronomic functioning of permanent grasslands within a farmland. To develop efficient agro-environmental schemes (Kleijn and Sutherland 2003) to preserve plant diversity in permanent grasslands, policy makers, stakeholders, advisers, and scientists must identify the crucial factors and associated mechanisms and quantify their effects. However, most scientific studies interested in such factors have examined the effects and mechanisms of only one or a few influential factors (e.g., grazing effects; Bullock and Pakeman 1996; Hickman et al. 2004) without considering other influential factors on plant diversity.

In this review, we aim to describe the primary factors and underlying processes that influence plant diversity in permanent grasslands. Our objective is to demonstrate that plant diversity in grasslands is determined by both fieldand landscape-scale factors. We describe the processes associated with each influential factor to distinguish the roles of: (a) farming practices carried out in permanent grasslands at the field scale and (b) landscape configuration, i.e., spatial structure and functional characteristics in areas surrounding grasslands. Moreover, we consider both taxonomic and functional approaches. We describe the effects of these factors on taxonomic diversity (species richness) and on functional groups based on functional properties (sensu Violle et al. 2007) of plant species. The advantage of a functional properties approach is that different plant communities may be compared, and general trends may be inferred (Diaz et al. 1998). Among influential factors, we do not describe the effects of edaphic conditions on plant communities because this subject has already been studied extensively (e.g., Janssens et al. 1998).

In terrestrial ecosystems, vegetation creates the basic habitat structure for many animal species. In addition, plants form the first trophic level of terrestrial food webs. They are eaten by herbivores, which provide food for carnivores and parasitoids, which in turn may be parasitized or consumed by predators (Pimm 2002). Perturbations of 
the vegetation also disturb higher trophic levels and hence the functioning of the agro-ecosystem as a whole (Wardle et al. 1999). Conversely, plants often need vectors for pollination (entomogamous plant species) and seed dispersal (zoochorous plant species). Plant species diversity in permanent grasslands cannot be explained simply by agricultural management schemes implemented at the local scale (i.e., the field scale). The surrounding landscape also plays an important role (Barbaro et al. 2004; Waldhardt et al. 2004), affecting seed dispersal (Geertsema et al. 2002; Rew et al. 1996) and pollen flow (van Geert et al. 2010).

Plant species expand their ranges through propagule dispersal (Rew et al. 1996). Pollination provides genetic mixing, which enhances genetic diversity and thus safeguards the adaptability and resilience of plants to natural or human constraints (Newman and Tallmon 2001). The surrounding landscape is regarded as a major filter of plant species and thus determines the regional pool of plant species (Belyea 2004; Dupré 2000; Ozinga et al. 2005). The regional species pool includes the set of species occurring in a certain region by migration, dispersal, or release from a seed bank (Belyea 2004; Zobel 1997). Competition for resources and resource use efficiency tends to favor some species within the regional pool (Balent et al. 1999; Belyea 2004). Filters including landscape configuration, farming practices, and inter- and intra-specific resource competition determine the actual species pool (Belyea 2004), i.e., the established vegetation in a given permanent grassland. Filter is considered as a factor preventing the development of plant species in a habitat.

The development of agro-environmental schemes to preserve or restore plant diversity in permanent grasslands requires an understanding of these factors and processes. Understanding these processes can help to predict the time lag between a change in one factor initiated by an agroenvironmental scheme and the observation of consequences in the grassland vegetation. Moreover, management schemes are implemented by individual farmers, but current schemes do not consider the capacity of each farmer to reach the objective of a particular scheme. Some expected results of agro-environmental schemes cannot be achieved by a single farmer but by all farmers sharing the same territory. In particular, when plant diversity or a given endangered species is affected by the surrounding landscape configuration, a single farmer cannot achieve the expected results of a conservation scheme. The objectives of the current review are: (a) to integrate knowledge of plant ecology in permanent grasslands and (b) to identify factors that can be adapted by individual farmers and factors that depend on several farmers within a territory.

We first present factors at the field scale, followed by factors at the landscape scale. We describe the effect of each factor on plant diversity and the major mechanisms by which changes occur. We summarize these factors and processes in a single table (Table 1). We propose a conceptual model of plant species richness based on three ecological challenges that act as environmental filters. We also propose a graphical representation of the interaction effects between plant dispersal abilities, disturbance due to farming practices, landscape heterogeneity, and forage productivity on the dynamics of plant species richness. We finally discuss the need to consider all of these factors to understand the plant species composition of permanent grasslands and the necessity to study plant communities using both taxonomic and functional approaches.

\section{Assessable factors at the field scale}

We took into account the influence of farming practices and the soil seed bank on grassland vegetation. We studied the effects and mechanisms of grazing, nutrient supply, and mowing. We did not examine the effects of herbicides and tillage because these practices are rarely employed in permanent grasslands and poorly documented in the literature (Rahman et al. 1993; Rice and Stritzke 1989; Sheley 2007; Tunnell et al. 2006), making it difficult to formulate generalizations (Kleijn and Snoeijing 1997). All factors and underlying processes described in this literature review are summarized in Table 1.

\subsection{Grazing}

Grazing affects plant diversity in permanent grasslands through the stocking rate (e.g., Diaz et al. 2001), the seasonality (e.g., Sternberg et al. 2000) and the livestock species used (e.g., Huntly 1991). A previous review (Diaz et al. 2007) has shown that grazing favors: (a) annual species, (b) species with a flat-rosette growth form, (c) stoloniferous or hemicrytophyte species, and (d) species with well-dispersed seeds (for example, small seeds or seeds with pappi). These results suggest the necessity to consider not only taxonomic indices but also plant functional ecology to evaluate the effects of farming practices such as grazing on grassland vegetation.

\subsubsection{Stocking rate}

Stocking rate is the number of grazing animals or livestock units per unit area. Grazing disturbs plant species composition in permanent grasslands (Hickman et al. 2004; Palmer et al. 2004). Generally, increased stocking rate is accompanied by an increase in species with the following functional properties: ruderal and competitive strategies (sensu Grime et al. 1988), particularly competitive grasses (Fig. 1, Dumont et al. 2009); annual life history; seasonal 


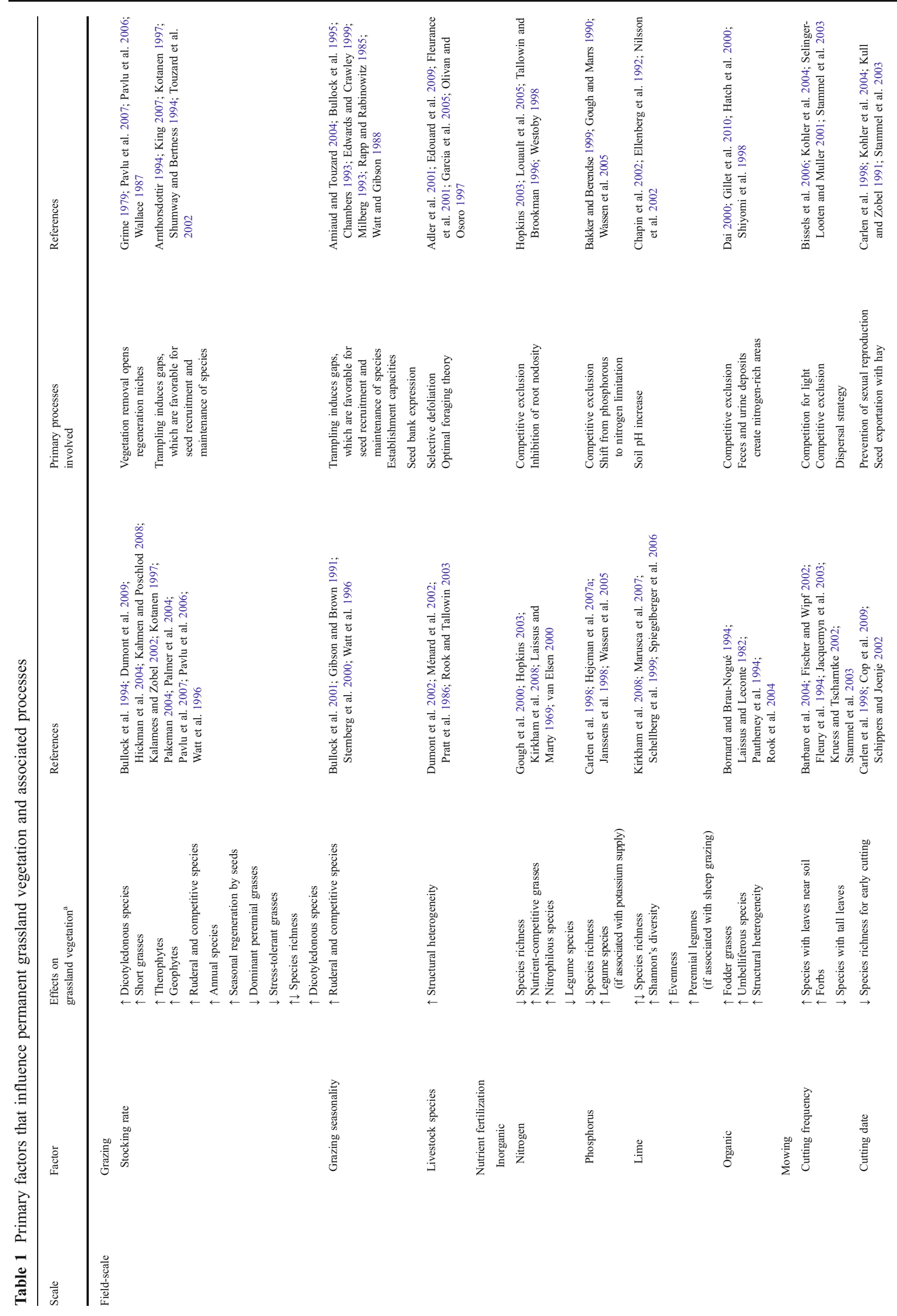


regeneration by seeds; flowering and seed dispersal early in the season; rosette habit; higher light requirements; and lower minimum height (Pakeman 2004). However, these consequences of increased stocking rate depend on site productivity and periodicity of such disturbance (Pakeman 2004). Conversely, low-stocking rate favors stress-tolerant grasses (sensu Grime et al. 1988) and forbs but depending on the starting floristic composition and site conditions (Dumont et al. 2009).

The richness of dicotyledonous species increases with increased stocking rate by sheep (Bullock et al. 2001). However, this relationship is valid only above a poorly defined threshold of stocking rate; a comparison of three low sheep grazing intensities (one, two, and four sheep per hectare) does not show any differences in the plant species composition of grassland vegetation (Calladine et al. 2002). Moreover, grasslands with intensive grazing exhibit higher proportions of dicotyledonous species (Bullock et al. 1994), short grasses such as Agrostis capillaris L. (Louault et al. 2005; Pavlu et al. 2007), therophytic and geophytic species (with versatile or flat rosettes), and species with mobile seeds (Kahmen and Poschlod 2008) compared with grasslands with low-stocking rate (McIntyre et al. 1995).

Stocking rate can influence the plant diversity of permanent grasslands through two mechanisms: removal of vegetation and trampling. Grazing by herbivores leads to spatial heterogeneity of the plant canopy (Wallace 1987) by selective defoliation, opening regeneration niches (sensu Grime 1979). Removal of vegetation allows light to reach the lowest vegetation layers and the soil surface, triggering competition for resources, such as the light (Rook and Tallowin 2003). Several plant species grow rapidly in canopy openings, especially creeping plants, such as Trifolium repens L. (Pavlu et al. 2007; Pavlu et al. 2006). Trampling induces gaps in the vegetation resulting from the death of established individuals. Such gaps can be created by many animals, including earthworms, ants, moles, gophers, and birds (King 2007), but livestock such as cattle, horses, and sheep are the most effective. These gaps are crucial for seedling recruitment and maintenance of plant species richness (Grubb 1977; Lavorel et al. 1994). Gaps facilitate the spreading of species by lateral vegetative growth and the recruitment of new species from the soil seed bank and seed rain by reducing competition with established species (Kotanen 1997).

Gap colonization is influenced by the size and shape of the gap (Arnthorsdottir 1994; Shumway and Bertness 1994) and the seasonality of gap formation (Touzard et al. 2002). The summer grazing mechanism was clearly through the opening of vegetation gaps, and superior gap colonizers plant species showed a more positive response to higher stocking rate (Bullock et al. 2001). For example, Silvertown and Smith (1989) observed that heavy grazing by sheep in 
a

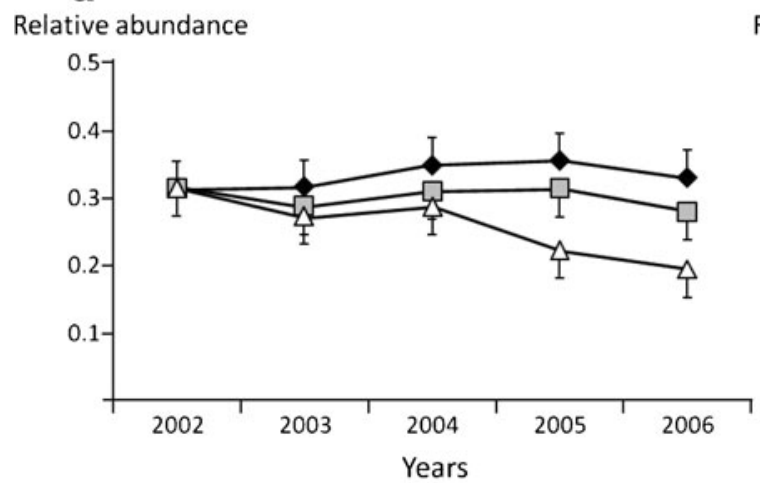

C

Relative abundance

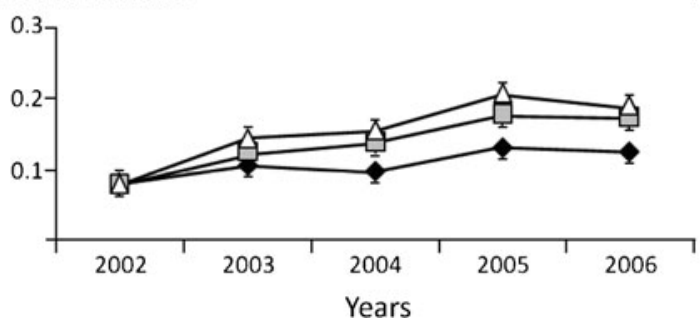

Fig. 1 Changes in the relative abundance of the main botanical families over a stocking rate experiment performed along five consecutive years. a An increase of relative abundance of competitive grasses of the C-S-R and $\mathrm{C}$ types in the C-S-R model of primary strategies ( $C$ competitive, $S$ stress-tolerant, $R$ ruderal) proposed by Grime et al. (1988) by increasing stocking rate, b an increase of

summer increased the frequency of small gaps, as well as the total area of gaps. The plants that colonize gaps may be derived from recently dispersed seed (i.e., seed deposited or produced at the site less than a year earlier), from the germination of persistent seeds from the soil seed bank (i.e., seed deposited or produced at the site more than a year earlier), or from ramet production from nearby individuals (Thompson and Grime 1979; Kalamees and Zobel 2002). Because most of the area of a small gap is close to an edge, such a gap should be recolonized by clonal plants and by short-range dispersal of propagules from immediately adjacent vegetation (Kotanen 1997). In contrast, revegetation of larger gaps could be slower and more strongly dominated by species with strong seed dispersal abilities (Connell and Slatyer 1977).

Stocking rate dramatically influences botanical composition of grasslands, working on the recruitment, survival, and dispersion of species. This factor selects species with traits which give to these plants a tolerance to trampling and removal of vegetation (Table 1). Due to a high level of interaction between the components of grazing and pedoclimatic factors, the total species richness and plant community dynamics are not linked to stocking rate in a linear relationship.

\section{b}

Relative abundance

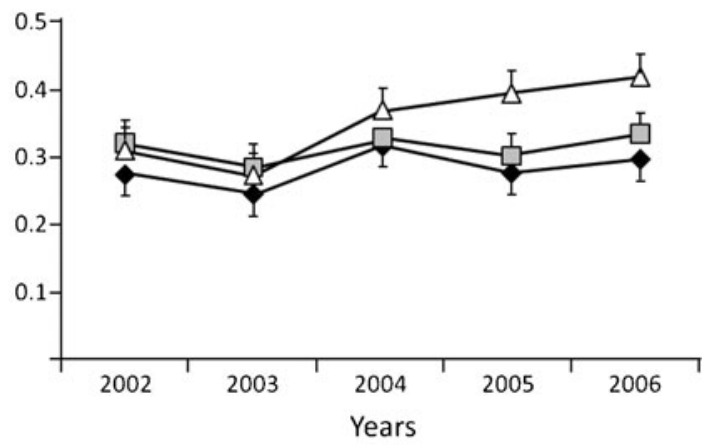

d

Relative abundance $\$ 1.4$ livestock Unit per ha

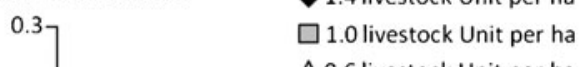

$\triangle 0.6$ livestock Unit per ha

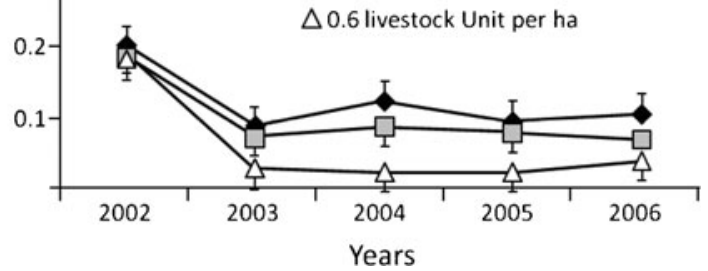

relative abundance of forbs with a stocking rate decrease, $\mathbf{c}$ an increase of relative abundance of stress-tolerant grasses of the S and S-C types of the same model with a stocking rate decrease, and $\mathbf{d}$ an increase of relative abundance of legumes when stocking rate increases (modified from Dumont et al. 2009)

\subsubsection{Grazing seasonality}

The influence of grazing seasonality by sheep seems to be study-dependent, ranging from beneficial for spring grazing (Bullock et al. 2001) to neutral, whatever the season (Bullock et al. 1994). Grasslands grazed by cattle throughout the year have greater plant species richness than the same grasslands grazed occasionally (Sternberg et al. 2000). Most other studies have found no effect of grazing seasonality on species richness (Gibson and Brown 1991; Smith et al. 1996). However, some authors (Bullock et al. 2001; Gibson and Brown 1991; Watt et al. 1996) have found that a combination of spring and winter grazing increases species richness in grasslands, while Bullock et al. (2001) have shown that heavy summer grazing decreases species richness in some grassland. Moreover, spring and winter grazing primarily increases the proportion of dicotyledonous species, such as legumes (Watt et al. 1996).

These responses of plant diversity result from the variation in the responses of individual plant species to grazing treatments in different seasons (Bullock et al. 2001). The increased occurrence of many species with winter grazing may be explained by their need for bare patches (formed by winter grazing) to allow seedling 
establishment (Watt and Gibson 1988) or re-growth from vegetative parts (Amiaud and Touzard 2004; Milberg 1993). The literature on the role of gap dynamics in herbaceous communities in relation to grazing seasonality is extensive (Bullock et al. 1995; Chambers 1993; Edwards and Crawley 1999; Rapp and Rabinowitz 1985). Gap creation during winter seems to be more important for the establishment of dicotyledonous species than reduced competition from dominant grasses through intensive summer grazing (Bullock et al. 1994; Watt et al. 1996). Indeed, summer grazing clearly affects species composition through the opening of vegetation gaps. Superior gap-colonizing species show a more positive response to heavy grazing (Bullock et al. 2001). Among superior gap-colonizing species, competitor-ruderal and stresstolerant ruderal species are favored by heavy grazing, despite their establishment abilities (Arnthorsdottir 1994; Kotanen 1997).

The effect of grazing seasonality on plant biodiversity in grasslands has not been extensively studied (Table 1). Various effects were found, most of studies showing no influence of this factor. A possible explanation is the diversity of mechanisms involved at the different seasons of grazing and the stage of plant development when grazing occurs.

\subsubsection{Herbivorous livestock}

Grazing maintains and enhances the structural heterogeneity of permanent grassland vegetation (Rook and Tallowin 2003) due to selective defoliation of plant species and organs by herbivores (Adler et al. 2001). Herbivorous species show different spatial and temporal patterns in their use of plant resources (Huntly 1991). Selective grazing between different plant communities and species has been shown for cattle (Pratt et al. 1986), horses (Ménard et al. 2002), and sheep (Dumont et al. 2002). Feeding choices vary depending on a wide range of factors, including animal condition, previous grazing environment, season, and species, breed, and gender of the animal (Illius and Gordon 1993).

Two primary mechanisms might explain selective grazing. First, forage nutritive value and biomass availability differ among plant communities and species. Horses focus their grazing activities on attractive sites with greater forage quality or nutrient content (Fleurance et al. 2001). Cattle have a similar diet selection strategy but use resources differently because they are less constrained by plant secondary metabolites (so they are able to use dicotyledonous species to a greater extent than horses) but more constrained by plant height (so they are unable to use short grasslands). Sheep consume more browse species than cattle because of their greater ability to select high-quality plant parts such as flowers and young shoots (Olivan and
Osoro 1997). Sheep modulate their foraging paths based on vegetative biomass abundance and/or sward structure (Garcia et al. 2005). For example, diet selection is influenced by plant sodium and phosphorous content (Wallis DeVries 1998). The legume species Lotus corniculatus L. has high sodium content, and its high palatability in grazed salt marshes (Amiaud et al. 1998) may have direct anthelminthic properties (Aerts et al. 1999). To avoid parasitism, horses avoid grazing in specific areas used for feces deposition (Rook et al. 2004). On the other hand, horses choose between vegetative patches of similar quality according to the predictions of optimal foraging models and select those that they can ingest more quickly (Edouard et al. 2009). The patch grazing model proposed by Adler et al. (2001) postulates that herbivores preferentially re-use species with high forage value in small previously grazed areas. Additive effects are usually found when two herbivorous species graze a resource in a similar manner, leading to stronger effects on plant communities. In contrast, herbivorous species show compensatory effects when their grazing patterns differ, leading to complementary use of plant resources (Loucougaray et al. 2004).

Due to contrasted preferences for the different species in the sward, grazing species induce various dynamic in grassland botanical compositions. Moreover, grazing generally enhances spatial heterogeneity (Table 1), either in a regular pattern (cattle, sheep) or distinguishing specific areas (horse). When associated, these animal species demonstrate additive or compensatory effects.

\subsection{Nutrient fertilization}

We distinguish between organic and inorganic nutrient fertilization. The primary difference between organic and inorganic fertilizers from a vegetative point of view is the differential nutrient supply that they provide to plants (Kirkham et al. 2008). The two forms of fertilizer may differ in their rates of nutrient release following application. Inorganic forms induce higher nutrient availability than fresh farmyard manure, one kind of organic fertilizer. Moreover, farmyard manure may increase the organic matter content of soil, thereby increasing moisture retention, which might favor more competitive species (Kirkham et al. 2008). We consider only nutrient addition by farmers. Thus, we do not consider nitrogen supply through atmospheric deposition, which can reach 5 to $35 \mathrm{~kg} \mathrm{ha}^{-1}$ year $^{-1}$ (Stevens et al. 2004).

\subsubsection{Inorganic nutrient fertilization}

Nitrogen Mineral nitrogen fertilization has a detrimental effect on plant diversity in permanent grasslands, decreasing plant species richness (e.g., Gough et al. 2000; 
Jacquemyn et al. 2003; Rajaniemi 2002). The effects of mineral nitrogen fertilization are generally shown by using a gradient of ammonium nitrate, the nitrogen fertilizer most used by farmers. Urea is also frequently used, but there is no differentiation in species composition between grassland plots fertilized with different nitrogen fertilizers (ammonium, nitrate, and urea) after 35 years (Galka et al. 2005). Nitrogen fertilization favors the growth of grasses with erect shapes that are able to take up nutrients from the soil rapidly and efficiently (Tallowin and Brookman 1996), such as Lolium perenne L., Festuca arundinacea Schrad., Phleum pratense L., and Poa pratensis L. (Laissus and Marty 1969). However, nitrogen fertilizers disfavor legumes (Laissus and Marty 1969), such as Trifolium sp. and Medicago sp., by inhibiting nodosity functioning (Hopkins 2003) and enhancing competition by grasses.

By favoring nitrophilous species (van Elsen 2000), especially grasses, mineral nitrogen fertilization induces competitive exclusion that leads to the disappearance of less-nitrophilous species. Some authors have shown relationships between the capacities of species to exploit resource-rich or resource-poor environments and key plant traits that drive these properties (Westoby 1998). Informative plant traits include specific leaf area (SLA), leaf dry matter content (LDMC), leaf nitrogen content, and leaf $\mathrm{C} / \mathrm{N}$ ratio (Ansquer et al. 2009). For example, species adapted to poor resource availability (low-growing or conservative species) have low SLA and N content and high LDMC and leaf $\mathrm{C} / \mathrm{N}$ ratio (Louault et al. 2005).

Nitrogen effects on plant biodiversity have been frequently demonstrated. Grasses, especially competitive species with a low leaf dry matter content, are greatly favored by nitrogen supply, while legumes being disfavoured. Finally, species richness decreases when the nitrogen fertility of soil is enhanced (Table 1).

Phosphorous Phosphorous application is the practice most responsible for decreasing species richness (Hejcman et al. 2007a; Janssens et al. 1998; Wassen et al. 2005). Phosphorous fertilization is more likely to cause species loss than nitrogen and lime enrichment (Hejcman et al. 2007b), particularly in high-moisture herbaceous ecosystems (Wassen et al. 2005). When nitrogen is not limiting, phosphorous is generally the growth-limiting nutrient (Bonischot 1989; Hejcman et al. 2007a). Phosphorous enrichment may increase productivity and decrease species richness through competitive exclusion; a shift from phosphorous limitation to nitrogen limitation is a disadvantage to species adapted to low phosphorous availability (Wassen et al. 2005). However, such a decrease of species richness can lead to a decrease of productivity when disfavoured species are highly productive ones such as tall grasses Alopecurus pratensis L., Arrhenatherum elatius (L.) P. Beauv., and Trisetum flavescens (L.) P. Beauv (Hejcman et al. (2007a). Coupled with potassium supply, phosphorous supply favors legume species (Carlen et al. 1998). Thus, phosphorous addition decreases species richness and affects the productivity of grasslands. The large phosphorous-pool accumulated in the soil over decades of fertilization might explain why re-establishment of endangered species on former agricultural fields generally fails (Bakker and Berendse 1999; Gough and Marrs 1990).

Phosphorous fertility of soil has a tremendous influence on species richness (Table 1). This nutrient must be considered just behind nitrogen as the most important nutrient factor regarding botanical composition.

Lime Diverse results have been obtained from studies about the effects of liming on grassland vegetation. When lime combined with farmyard manure is applied for the first time on species-rich meadows, species richness decreases (Fig. 2, Kirkham et al. 2008). Other studies have detected no effect of liming on vegetation (Galka et al. 2005; Tzialla et al. 2002). Finally, a positive effect of liming on Shannon's diversity, evenness (van der Wal et al. 2009), and species richness (Schellberg et al. 1999; Spiegelberger et al. 2006) in grasslands has been demonstrated. Moreover, the positive effect of liming on species richness can still be detected 70 years after the last treatment (Spiegelberger et al. 2006). This positive effect can be explained by the increase of soil $\mathrm{pH}$ induced by liming.

In acid soils, plant species richness increases with soil $\mathrm{pH}$ increasing (Nilsson et al. 2002) until neutrality is reached. In continental Europe, more vascular plants species are suited for high-pH soils than for acidic soils (Ellenberg et al. 1992). Moreover, soils with $\mathrm{pH}$ values close to neutrality generally have higher nutrient availability than soils with $\mathrm{pH}$ values between 4 and 5 (Chapin et al. 2002). Liming also alters vegetation composition. Liming increases the number of species representing oligotrophic grassland communities (Schellberg et al. 1999) and stimulates perennial legumes, especially hybrid and white clover, when combined with sheep grazing (Marusca et al. 2007).

The influence of lime on botanical composition and species richness is much debated in the literature than nitrogen or phosphorus (Table 1). Various results were obtained, depending on pedoclimatic conditions, and the $\mathrm{pH}$ modifications induced by lime application.

\subsubsection{Organic nutrient fertilization}

Organic nutrient supplies include fresh or composted manure, liquid manure, and feces spread during grazing. The effects of organic nutrient fertilization depend on the 


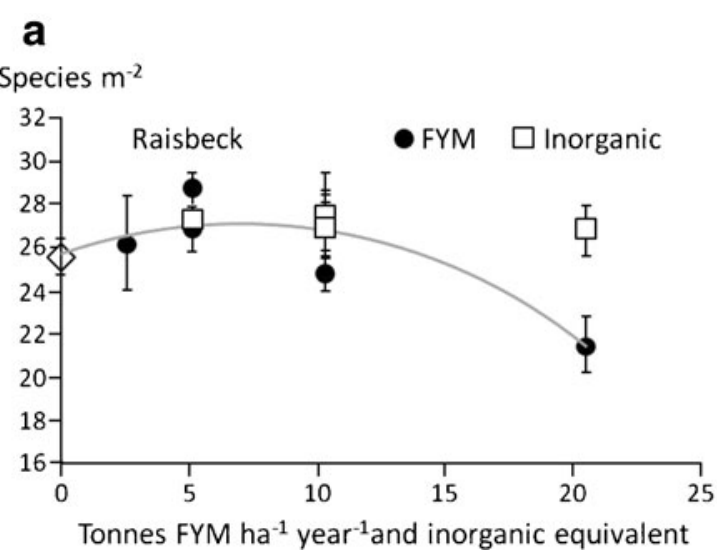

Fig. 2 Relationships between the mean amount of farmyard manure (FYM) or inorganic equivalent fertilizer applied per year averaged over 1999-2005 and species richness in 2005 at two hay meadow sites (a Raisbeck and b Gaisgill). Each point represents the mean of three replicate plots. Error bars are the standard error of the mean in each case. The gray line or curve shown on each graph was fitted using

level of fertilization, the site conditions, and the initial botanical composition of the sward (Kirkham et al. 2008). These authors showed that species richness decreased with farmyard manure level of fertilization (Fig. 2). Stopping farmyard manure fertilization causes a change in the abundance of species. For example, the absence of farmyard manure resulted in decreased cover of Poa trivialis and Rumex acetosa and an increase in five other species. The absence of fertilizer gave a similar response, but $A$. capillaris declined in mesotrophic grasslands (Smith et al. 2002). Organic nutrient supply favors the growth of fodder grasses (Bornard and Brau-Nogué 1994) and umbelliferous species, especially in wet grasslands (Pautheney et al. 1994). Although the primary effects of organic fertilizers on productivity and species richness in permanent grasslands are the same as those of mineral fertilizers, different forms of organic fertilizers sometimes have distinct effects on plant species composition. Compared with composted manure addition, liquid manure spreading increases the abundance of several good fodder plant species such as $L$. perenne, $P$. pratense, and Festuca pratensis Huds. and decreases the abundance of others like Dactylis glomerata L., Holcus lanatus L., and A. pratensis (Laissus and Leconte 1982).

The deposition of decomposable feces and urine can create nitrogen-rich areas (Dai 2000) and stimulate the mineralization of nitrogen (Hatch et al. 2000). Manure in dung piles increases the availability of soil nutrients, especially nitrogen and phosphorus (Aarons et al. 2004) and favors the conservation of humidity (Dai 2000). This process might contribute to the development of special patches of vegetation growing directly on or close to manure deposits (Shiyomi et al. 1998). Herbivores can therefore indirectly influence the nitrogen cycle by altering species composition and plant biomass (Olofsson et al.

\section{b}

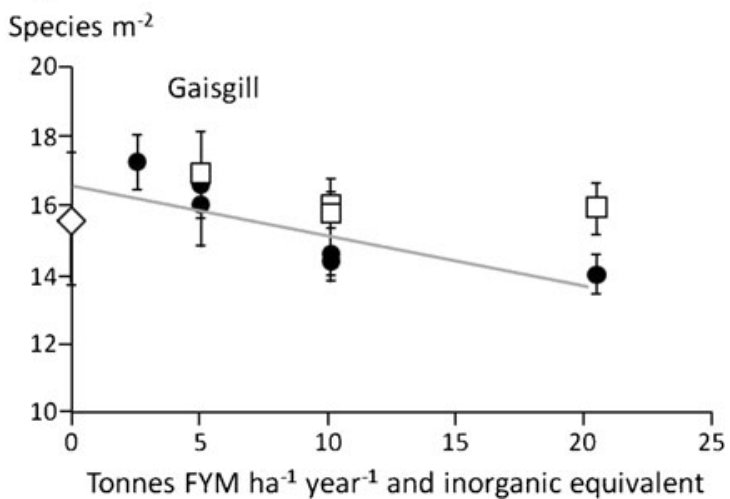

linear or polynomial regression analysis of data from FYM-treated plots (without lime). A parabolic relationship $\left(y=25.7+0.41 x-0.03 x^{2}\right)$ was fitted for FYM at Raisbeck and negative linear one $(y=16.5$ $0.14 x$ ) at Gaisgill. No significant relationship was shown with inorganic equivalent treatments (modified from Kirkham et al. 2008)

2001). In some cases, dung piles cover a significant portion of permanent grassland areas, produce significant changes in vegetation and are associated with invasive alien plants that might eventually colonize more areas (Dai 2000). Feces are beneficial for the establishment and survival of seedlings (Gillet et al. 2010). Moreover, germination of seeds contained in feces is improved by gut passage, which softens the seed coat (Malo and Suarez 1995).

Organic fertilization modifies botanical composition of grassland not only because of their nutrient content (nitrogen and phosphorus), but also in relation to seed transport and to the consequences on soil properties (structure, water conservation; Table 1). As a result, specific species can be found or dominate in grassland receiving high amount of organic fertilization.

\subsection{Mowing}

Compared with grazed situations, the vegetation of mown grasslands is generally more diverse when the number of mowing is low (one or two cuts per year; Fig. 3, upper and second photos; Fischer and Wipf 2002; Jacquemyn et al. 2003; Kruess and Tscharntke 2002), for example, mowing seems to favor forbs (Stammel et al. 2003).

The effects of mowing in permanent grassland vegetation depend on cutting frequency and/or cutting date (especially first cutting date) based on the flowering stage of grasses (Barbaro et al. 2004; Fleury et al. 1994) and initial floristic composition of grasslands (Smith et al. 1996). Moreover, mowing can bring a large amount of seeds into permanent grasslands. Hay machinery (Fig. 4) can transport and disseminate several hundred thousand seeds across long distances from grassland to grassland (Strykstra et al. 1996; Strykstra et al. 1997). 
Fig. 3 Difference of mown grassland vegetation facies according to the number of cutting by year, in Lorraine (France): upper picture concerns grassland with only one cut per year inducing higher heterogeneity and species richness $\left(27\right.$ species $\left.\mathrm{m}^{-2}\right)$ than in the second picture representing grassland with three cuts per year (only 10 species $\mathrm{m}^{-2}$ )
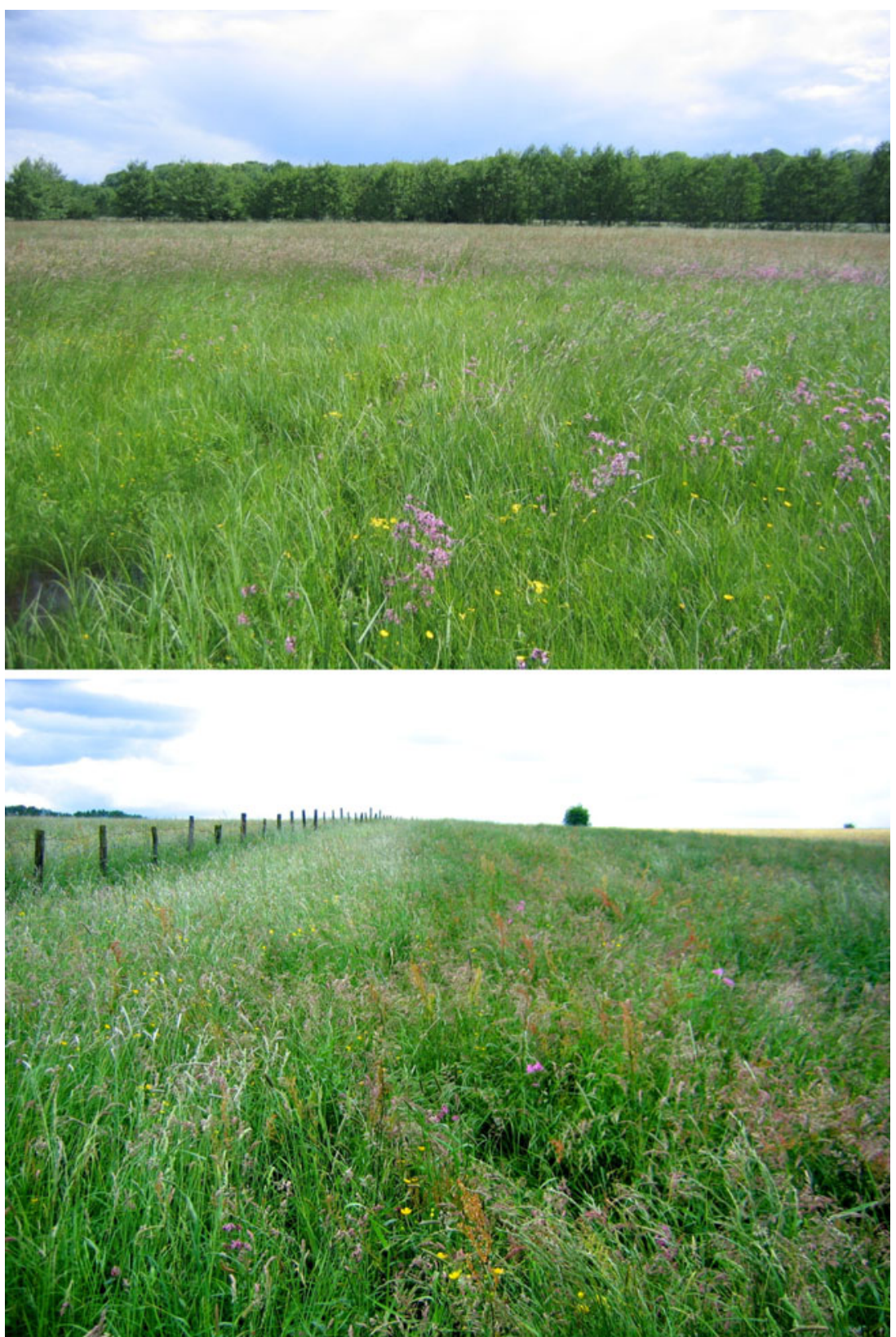

The number and dates of yearly cuttings affect the composition of grassland vegetation. For example, cutting regime explains $4.7 \%$ of total floristic variability (compared with $6.0 \%$ for stocking rate) in calcareous grasslands (Barbaro et al. 2004). Mowing date constitutes an important component of floristic composition because cutting too early can prevent seed production by nonclonal species, while cutting too late can result in dense vegetative cover that may inhibit the establishment of new plants (Smith and Haukos 2002).

These effects have been observed under natural recruitment conditions and in experiments with an artificial seed contribution for biodiversity restoration (Bissels et al. 2006). In restoration operations, early mowing can create openings in the vegetation that are favorable to the establishment of new species (desired or invasive; Selinger-Looten and Muller 2001). Maximum specific diversity is observed for mowing dates from mid-June to mid-July in European zones with oceanic or semi-continental climates (Critchley et al. 2007). Mowing dates affect permanent grassland vegetation according to plant flowering times. For plants with sexual reproduction, cutting before flowering prevents reproduction. If cutting occurs just before seed dispersal, a proportion of the seeds are exported with hay (Smith et al. 2002). In both cases, plant species richness generally decreases (Smith et al. 2002).

High cutting frequency (three or four times a year) favors species with leaves located near the soil, such as 
Fig. 4 Mowing of grasslands induces dissemination of seeds into the mowing field and also along roads due to hay machinery and forage carriage

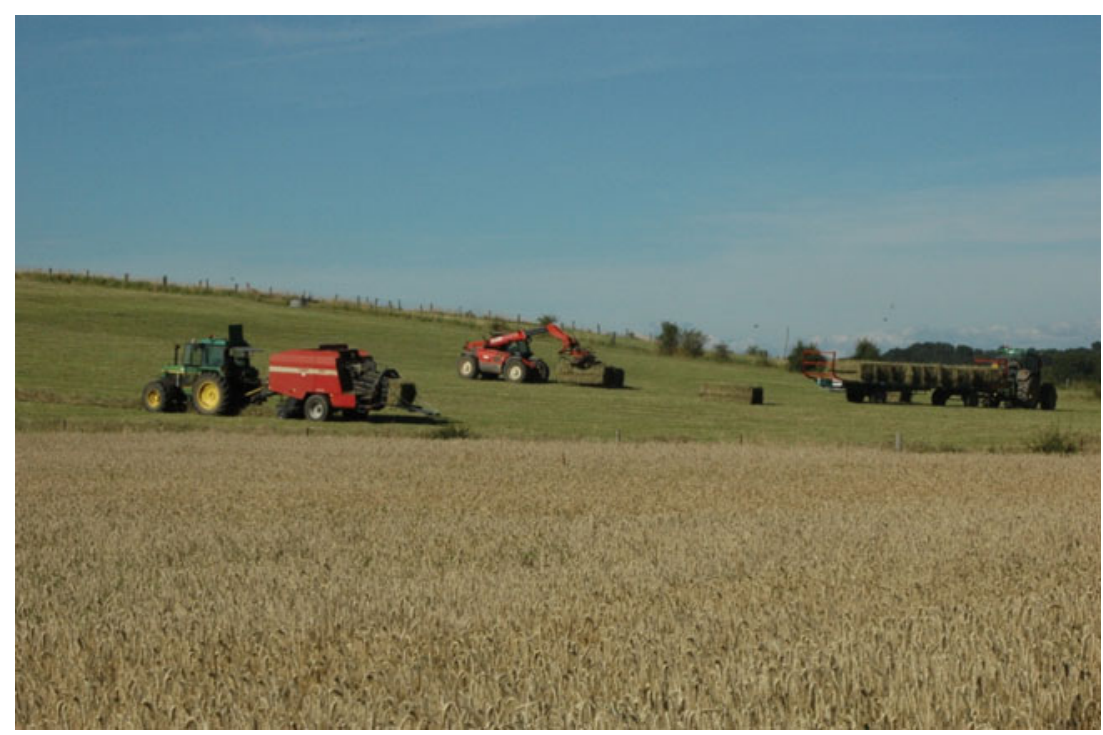

Taraxacum officinale Weber, $P$. trivialis L., and P. pratensis $\mathrm{L}$, and species that take advantage of increased light near the soil surface, such as T. repens (Carlen et al. 1998). High cutting frequency disfavours plant species with tall leaves, such as T. flavescens and Pimpinella major (L.) Huds. However, other species are insensitive to cutting frequency, such as $F$. pratensis Huds., Ranunculus acris L., and D. glomerata (Carlen et al. 1998), and the proportion of specific legumes like Vicia cracca L. and Lathyrus pratensis L. decreases as the number of cuttings increases (Cop et al. 2009). For other legumes like T. repens, increasing the cutting frequency leads to their development by increasing accessibility to light (Panos and Silander 1992) and by reducing competition with neighbors (Barthram et al. 1999).

Mowing favors some species and disfavours others according to their capacity to tolerate cutting, such as by rapidly producing new leaves just after mowing. A few species, including Anthoxanthum odoratum L., D. glomerata, and H. lanatus, can withstand mowing and removal of forage (Schippers and Joenje 2002). Mowing enhances the amount of light in the lower vegetation layers, making competition for light more symmetrical and facilitating the coexistence of species with different competitive abilities (Kull and Zobel 1991). A functional approach through the study of plant traits (Violle et al. 2007) has demonstrated the presence of rosette species with slow lateral spread and anemochorous dispersal under mown conditions (Kohler et al. 2004; Stammel et al. 2003).

Vegetation in mown grasslands is generally more diversified than in grazed ones, mainly because of more favorable conditions for seed dispersion of established species and recruitment of new species. Late first cutting dates favor grassland biodiversity, rarely earlier dates, and very late exploitations may induce a decrease in species richness (Table 1).

\subsection{Soil seed bank}

The soil seed bank comprises all "viable seeds present in or on the soil, including both those that germinate within a year of initial dispersal and those that remain in the soil for longer periods" (Nathan and Muller-Landau 2000). The soil seed bank can be a source of plant species. Most studies of grasslands dominated by perennial grasses have found low similarity between the seed bank and the vegetation (Lopez-Mariño et al. 2000; Milberg 1993; Peco et al. 1998). For example, Lopez-Mariño et al. (2000) have observed 119 plant species in aboveground grassland vegetation and 124 species in the soil seed bank, with only 52 species common to both the aboveground vegetation and the soil seed bank. These discrepancies have been explained by the minor contribution of the dominant perennial grassland species to the formation of seed banks. These species generally have low seed production because they alternate sexual reproduction with vegetative reproduction and their seeds have short-term persistence in the soil (Bakker 1989; Thompson et al. 2003; Thompson and Grime 1979). Where important seed banks are present in perennial grasslands, they often contain large numbers of seeds of annual ruderal species (Zimmergren 1980), reducing the similarity between the vegetation and the seed bank. Seeds of such species can survive for many decades, even centuries, in the soil (Milberg 1993). Thus, these species can reappear from the seed bank if grassland is ploughed or disturbed (Dutoit et al. 2003).

The potential of the seed bank to be a source of colonization depends on seed persistence in the soil, seed age, and soil conditions (mainly moisture content; ter 
Heerdt et al. 1999), on the depth of burial (Akinola et al. 1998) and on seed abundance (Blackshaw et al. 2005), modulated by seed predation (Martinkova et al. 2009b). These two last points (depth and abundance) might explain why the soil seed bank seems to play a minor role in the reestablishment of species in grasslands and in floristic modifications (Akinola et al. 1998). The minor role of the seed bank might result in part from soil compaction due to spring grazing in wet conditions, which prevents seedling emergence after disturbance. Rather, plant recolonization in disturbed areas is often dominated by vegetative reproduction. However, the study of the soil seed bank is of interest for two reasons. First, the seed bank partly reflects the past and present aboveground vegetation of the surrounding landscape (Geertsema et al. 2002). Seeds in the seed bank come from established aboveground vegetation and from outside grasslands. Seeds can be dispersed by animals, wind, and farm machinery across long distances (Geertsema et al. 2002). Second, soil seed banks contain species that are not present in aboveground vegetation (e.g., Amiaud and Touzard 2004; Edwards and Crawley 1999; Smith et al. 2002), and knowledge of seed bank composition is necessary to estimate total plant diversity in a particular permanent grassland.

Due to the past management of most grasslands, their soil seed bank is quite diverse, but their current management result in a poor correlation with the present botanical composition. Thus, soil seed bank is a resource for farmers to increase species richness of sward in permanent grasslands (Table 1).

\section{Assessable factors at the landscape scale}

The landscape is defined as a level of ecological system organization above the ecosystem (Fig. 5). It is character- ized by heterogeneity and by dynamics that are partly governed by human activities (Burel and Baudry 1999). The landscape results from continuous confrontation between society and its environment (Baudry et al. 2000; Burel and Baudry 1999). A landscape must be objectively described to test its potential relationship with established vegetation within it. Three primary ecological characteristics of landscape can be described: landscape heterogeneity, habitat fragmentation, and habitat connectivity (Burel and Baudry 1999; Forman and Godron 1981). Through these characteristics, we can structurally and functionally describe a target landscape. The structural aspects of a landscape are determined by landscape heterogeneity and habitat fragmentation. The functional aspects of a landscape are determined by habitat connectivity and habitat fragmentation. According to objectives, characterization of landscape structure or landscape function, habitat fragmentation is evaluated with distinct landscape indices (McGarigal and Marks 1995). Landscape configuration affects permanent grassland vegetation primarily by influencing seed rain. Seed rain is the "flux of seeds from a reproductive plant, without considering space explicitly" (Nathan and Muller-Landau 2000).

The description of landscape structure provides information about the availability and diversity of seed sources in the landscape surrounding the target grassland (Rosenzweig 1995). The description of functional aspects of a landscape provides information about dispersal possibilities through the landscape surrounding the studied grassland from suitable sources. Furthermore, the species composition of the seed rain reaching given grasslands is similar to the species composition of the established vegetation in the grassland (Edwards and Crawley 1999). Thus, by affecting seed rain, landscape configuration also affects permanent grassland vegetation. Seed dispersal from a source to the target grassland depends on the plant life cycle, seed size,

Fig. 5 Farmland in Lorraine (France) with high landscape heterogeneity in terms of land uses (forest, rape seed, grasslands, bare soil, winter wheat, barley, urban area, roads, hedgerows...)

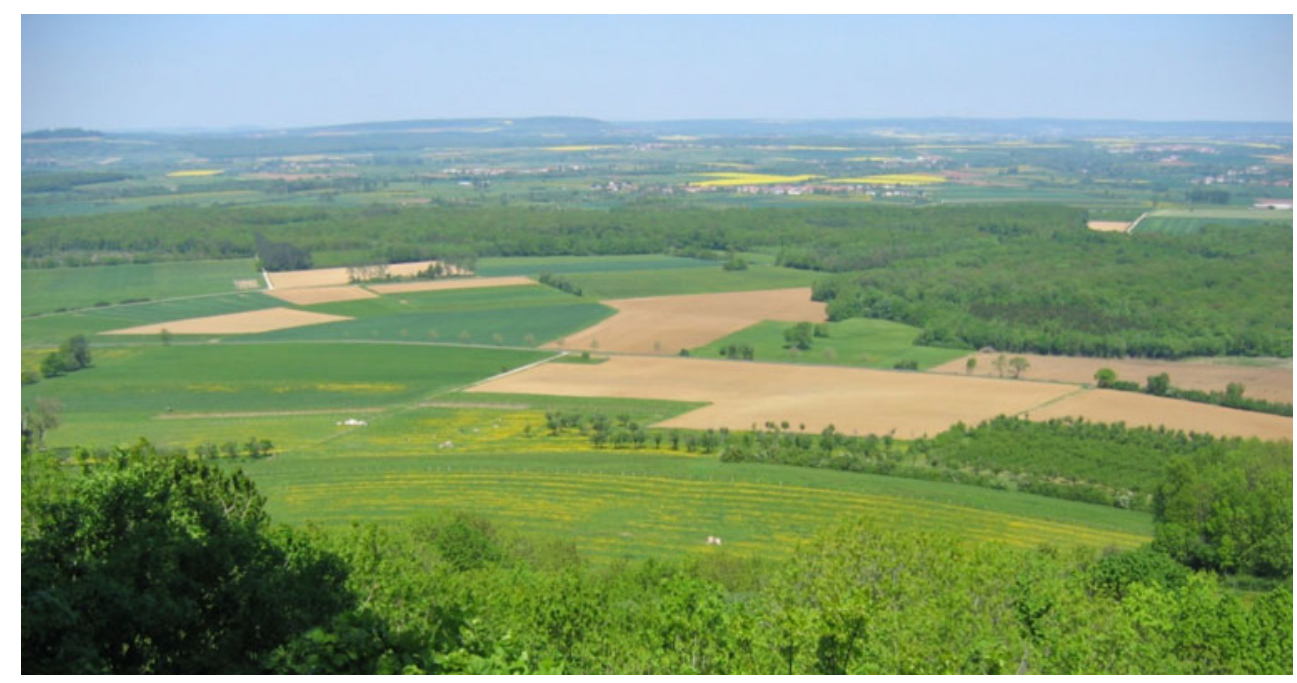


dispersal date, and functional characteristics of landscape. For instance, seeds of Bromus sterilis L. are dispersed further in open landscapes than in mixed woodland and pastures, in which hedgerows stop wind-dispersed seeds of this grass (Rew et al. 1996). Below, we describe the effects of these three primary landscape characteristics - heterogeneity, fragmentation, and connectivity - on vegetation and the associated processes.

\subsection{Landscape heterogeneity}

\subsubsection{Definition and primary effects on plant species in farmlands}

Landscape heterogeneity provides information about the diversity of landscape elements in a given landscape. Landscape elements generally correspond to different land uses within a landscape, which may be more or less precisely defined. They might include urban area, forest, arable land, fallow land, and permanent grassland (Dauber et al. 2003). The most popular index of landscape heterogeneity is based on the Shannon-Weaver formula (Shannon and Weaver 1949), which is used by ecologists to estimate species diversity. Calculating this index requires the proportion of each considered landscape element in the studied landscape (e.g., Weibull et al. 2000). Heterogeneity can influence plant composition in permanent grasslands through the creation of a diversified regional species pool and by providing refuges for plant species (Benton et al. 2003; Rosenzweig 1995). A landscape with a high heterogeneity index contains many different elements and thus many different potentially suitable habitats (Rosenzweig 1995).

Theoretically, greater landscape heterogeneity permits a richer regional species pool. This correlation has been demonstrated in the Morvan Natural Regional Park (Burgundy, France), where mean plant species richness randomly sampled at the plot scale is significantly correlated to landscape heterogeneity (Fédoroff et al. 2005). A similar result has been demonstrated through a predictive model of plant presence in agricultural fields based on the mosaic concept (Duelli 1997) and considering as inputs the number of landscape elements such as habitat types and the number of patches of each landscape element (Waldhardt et al. 2004). This potential increase of species richness in farmlands with increasing landscape heterogeneity involves an increased number of seed sources.

According to source-sink models (Wagner and Edwards 2001), landscape elements in the surroundings of a field are potential sources of plant species via propagule dispersal, and the target grassland is a sink. Therefore, high landscape heterogeneity in a given landscape might be expected to enhance colonization probability (Gabriel et al. 2005). High habitat richness of a heterogeneous landscape creates refuges for sensitive plant species if strong selective pressures are applied in several parts of the landscape (Roschewitz et al. 2005; Smart et al. 2002). Establishment in refuges is one way for sensitive species to grow and complete their life cycles until the dispersal of their propagules through nearby areas.

\subsubsection{Effects and processes of landscape heterogeneity}

In the case of grassland vegetation, results differ between available studies. Considering all herbaceous plant species of grasslands, Dauber et al. (2003) and Krauss et al. (2004) have found no correlation between species richness and landscape heterogeneity, whatever the spatial scale considered $\left(0.007\right.$ and $0.13 \mathrm{~km}^{2}$ in Dauber's study and from 0.2 to $28.3 \mathrm{~km}^{2}$ in Krauss's study). The lack of correlation might be explained by a greater influence of local habitat quality than of landscape heterogeneity (Dauber et al. 2003; Krauss et al. 2004). Dauber et al. (2003) has suggested that absence of a relationship was due to farming practices that disturb plant colonization and/or the plant matrix, which provides a source of rhizomes and diaspores over a short distance. Krauss et al. (2004) have suggested that the surrounding landscape of the studied grasslands is too complex, whatever the scale considered, to highlight an effect on permanent grassland vegetation. In other words, the range of variation of landscape heterogeneity might not be sufficient to demonstrate a significant relationship between plant species richness and landscape heterogeneity. In contrast, a positive and significant relationship between the species richness of permanent grasslands and landscape heterogeneity has been found when the latter is characterized using percentage cover of arable land in a $1 \mathrm{~km}^{2}$ territory (Söderström et al. 2001).

Overall, positive effects of landscape heterogeneity on plant species richness have been observed (e.g., Fédoroff et al. 2005; Krauss et al. 2004). Generally, this positive relationship can be explained by an increasing number of habitat types with increasing landscape heterogeneity (Rosenzweig 1995) and thus a larger regional species pool. Not all plant species are affected by landscape heterogeneity. Many authors have distinguished several groups of plant species according to functional properties (Weibull et al. 2000; Weibull and Östman 2003). Generally, a distinction (Fig. 6) has been made between habitat specialists and habitat generalists (Krauss et al. 2004; Söderström et al. 2001). Söderström et al. (2001)) have inferred that species richness of habitat generalists is higher in forests, which can act as a source of plant species for permanent grasslands in the vicinity.

For habitat specialists of permanent grasslands, there is a significant positive correlation between species richness 
Fig. 6 Increase of plant species richness with grassland area increase ( $n=31$ fragments). The slope is weaker for specialist plant species (66 species; $\left.y=13.64+6.32 \log _{10} x\right)$ than for generalist plant species $(242$ species; $y=1.40+15.44 \log _{10} x$; modified from Krauss et al. 2004)

\section{a}

Habitat specialist plant
species richness

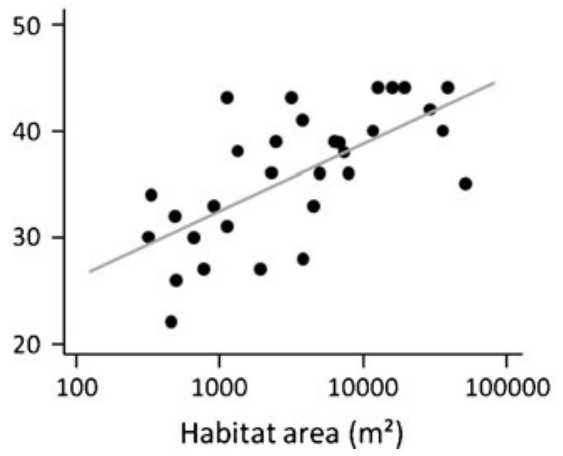

b

Habitat generalist plant species richness

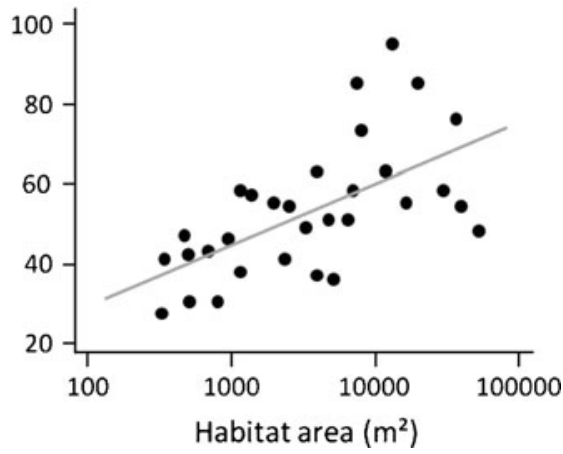

and landscape heterogeneity at a small scale $\left(0.2 \mathrm{~km}^{2}\right)$, but this relationship disappears when the analysis includes field area as a covariable (Krauss et al. 2004). We infer that the increasing number of habitat types with increasing landscape heterogeneity explains this relationship. Alternatively, species could be classified according to seed dispersal mode. For example, anemochorous species are more sensitive to landscape heterogeneity than barochorous species (Gaujour et al. 2009). Dispersal of anemochorous seeds might be affected by few particular landscape elements, such as hedgerows (Rew et al. 1996). Hedgerows can partly block seed flow through a landscape either by forming physical barriers or by decreasing wind speed. Differences in seed dispersal make it necessary to specify the spatial scale used to characterize landscape configuration. The choice of scale must take into account the functional properties of plant species, especially seed dispersal modes and theoretical dispersal distances (Vittoz and Engler 2007).

\subsubsection{Landscape elements}

Among landscape elements used to calculate landscape heterogeneity, some seem to be more influential on grassland vegetation, such as the percentage of ley area (Weibull and Östman 2003) and the percentage of arable land (Söderström et al. 2001). Plant species richness is higher in field margins when farmland contains a large percentage of ley, because this type of cover is less subject to farming perturbations than other types of cover, such as cereals (Weibull and Östman 2003). Thus, farmland with a high percentage of ley might contain a greater diversity of plant species than another farmland with same total area and less ley cover. However, because permanent grasslands contain diverse plant species of many functional types, it is crucial to consider the landscape as a mosaic of land uses seen as distinct habitat types that are more or less suitable for particular species. It could be useful to make these land uses precise according to farming management, in particular, permanent grasslands. Permanent grassland is not really a single kind of habitat. Different managements create different types of habitat, particularly for plant species. Then, a given permanent grassland could be an efficient source of species for another grassland with distinct management. The interest of grassland management heterogeneity at landscape scale for plant diversity in studied grassland is not documented. This could be due to the lake of large landscapes with information about farming practices.

The mosaic of land uses that form landscape can be seen as distinct habitats that are more or less suitable for plant species. By creating a diversity of refuges and enhancing colonization probabilities, the heterogeneity of this mosaic tends to favor the increase of species richness in permanent grasslands. However, this effect depends on the spatial scale used to characterized landscape configuration and initial state of this landscape.

\subsection{Habitat fragmentation}

Habitat fragmentation results from partial destruction of the initial area of a habitat type, leading to several disconnected habitat patches. For example, heathland habitat once extended over several million hectares in Europe. Due to changes in land use, including ploughing, abandonment, and drainage of heathland, the total area has strongly decreased and nowadays of many small patches that are more or less connected (Piessens et al. 2004; Webb 1998). Habitat fragmentation reduces the area available for certain species and thus leads to shrinkage and isolation of remnant plant populations (Joshi et al. 2006; Piessens et al. 2004; Saunders et al. 1991). Habitat fragmentation is not only habitat loss but also modification of habitat quality, reducing continuous available habitat and increasing edge effects (Burel and Baudry 1999). 
Habitat fragmentation may disrupt biotic interactions such as pollination or seed dispersal for individual species or populations (Lennartsson 2002) and hence can affect species with previously stable populations (Joshi et al. 2006). Fragmentation might alter gene flow between populations in different habitat patches, which could lead to declining fitness by decreasing the genetic variation of each remnant population and thus reproductive success (Ingvarsson 2001; Newman and Tallmon 2001).

Overall, results are inconsistent across taxa and experiments concerning the effects of habitat fragmentation on plant species (Debinski and Holt 2000; Joshi et al. 2006). In most of the studies considered in the review of Debinski and Holt (2000), habitat fragmentation contributed to a negative effect on plant species richness (e.g., Piessens et al. 2004). However, some positive effects can be explained by an increase in early successional species, by invasion from the surrounding area, by crowding effects, or by the ability of few species to use both the matrix habitat and the fragment (Debinski and Holt 2000). The lack of consistency highlighted by Debinski and Holt (2000) might be explained by differences in species responses according to their functional properties, by the variable and possibly insufficient duration of experiments, and by the lack of control treatments due to the spatial scale considered in such studies.

In this section, we detail the effects of habitat fragmentation on plant species. We divide the effects of habitat fragmentation into two parts, as described in Burel and Baudry (1999): the fragment area effect and the edge effect. We highlight the consequences of habitat fragmentation for plant community composition, not the abiotic consequences in microclimate (see Saunders et al. 1991; Weathers et al. 2001). Because forest ecosystems and agricultural ecosystems have distinct functions, we do not review studies about the impact of forest fragmentation on plant species, even though this process has been studied extensively.

\subsubsection{Fragment area}

The theory of island biogeography (MacArthur and Wilson 1967) can help us to predict the effects of fragment area on plant communities by considering each fragment as an island. According to this theory, the species richness of a given fragment depends on the extinction rate and the colonization rate. Fragment area affects these rates: a large fragment provides resources for more species than a small one (Rosenzweig 1995), and thus a large fragment induces a lower extinction rate than a small one. Fragment size is positively correlated with colonization rate because the probability that species will find an island increases with island area (MacArthur and Wilson 1967). Finally, the theory of island biogeography predicts larger fragments will have greater species richness. However, use of this theory at the landscape scale in farmlands needs precautions. In particular, fragments cannot be considered as true islands because the surrounding habitat is often not completely hostile to the studied species (Farina 2007; Gu et al. 2002).

The theory of island biogeography can be effectively combined with percolation theory (Johnson et al. 1992), which considers the abilities of organisms to cross different kinds of adjacent fragments. In spite of this constraint of considering fragments as islands, the predicted positive relationship between species richness and fragment area has not been consistently verified for plants. This relationship can be positive (e.g., Cousins et al. 2007; Piessens et al. 2004) or not significant (e.g., Cousins 2006; Cousins and Aggemyr 2008). In the review of Debinski and Holt (2000), six out of 14 studies showed increasing species richness with increasing fragment area. As with habitat fragmentation, the effects of fragment area on vegetation are not homogeneous.

The positive relationship between fragment area and species richness is significant for heathland vegetation in Western Europe (Piessens et al. 2004), dry grasslands in Denmark (Bruun 2000), calcareous grasslands in Germany (Krauss et al. 2004), and semi-natural grasslands in Sweden (Öster et al. 2007). These positive effects of fragment area on plant species richness are primarily explained by increasing habitat heterogeneity with increasing fragment area (Bruun 2000; Krauss et al. 2004; Öster et al. 2007). A second explanation is the fact that smaller fragments may contain plant species that are more sensitive to extinction (Piessens et al. 2004). Experiments in several calcareous grassland sites in the Swiss Jura Mountains using microfields (from 0.25 to $20.25 \mathrm{~m}^{2}$ ) have shown less clear results (Joshi et al. 2006). These experiments verify that, whatever the study site, the increase of fragment area has a negative effect on species extinction rate (Fig. 7), as predicted by theory of island biogeography from MacArthur and Wilson (1967). However, the effect of fragment area increase on species colonization rate could also be negative, contra-
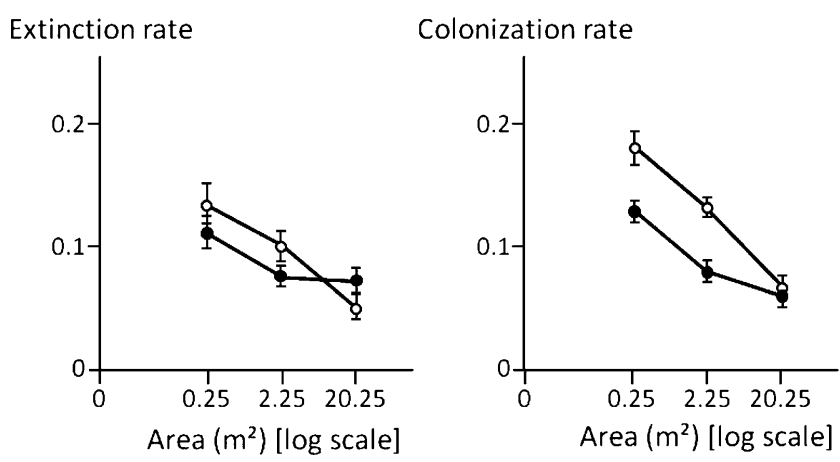

Fig. 7 Decrease of extinction rate and colonization rate, respectively, with increasing of plot size, in fragments (closed circles) and control mown grasslands (open circles) over 7 years, between 1993 and 1999. Vertical bars denote $\pm 1 \mathrm{SE}$ (from Joshi et al. 2006) 
dicting the first expectation of island biogeography theory. But, this theory also predicts that, when a large fragment already contains a large number of species, fewer new species can be added (MacArthur and Wilson 1967). Joshi et al. (2006) have invoked this theoretical expectation to explain their results. Moreover, the theory of island biogeography has been built from larger fragments (several hundred square meters) than the study of Joshi et al. (2006). This difference in fragment area could also partly explain their results.

The theory of island biogeography also predicts that habitat specialists will be more negatively affected by fragment area than habitat generalists. Habitat specialists generally are found in the core area of fragment. But, the fragmentation decreases the core area-edge ratio by increasing edge length and thus suitable habitat for generalist species. Then, this leads to relatively greater loss of core area which is the suitable habitat for specialist species. This prediction is not supported for calcareous grassland vegetation, where fragment area has been observed to have equal effects on specialist and generalist plant species (Krauss et al. 2004).

Fragment area also affects negatively species richness of the soil seed bank in dry grasslands, particularly for species with transient seed banks compared with species with longterm persistent seed banks, which are slightly affected (Bruun 2000). We infer that even with a low immigration rate, species with long-term persistent seed banks can persist in small fragments thanks to the small amount of seeds in the soil.

\subsubsection{Edge effect}

Habitat fragmentation also increases the length of edges of landscape elements (Burel and Baudry 1999). These edges of landscape elements are called field margins. Two adjacent field margins form a field boundary (Marshall and Arnold 1995). From an ecological point of view, field boundaries are ecotones, areas of vegetation transition that are usually narrow and clearly defined and that divide two distinct plant communities established in adjacent agricultural fields (Dutoit et al. 2007). Field boundaries can act as sources of species for grasslands because species richness is generally higher in edges than in field centers (Aude et al. 2003; Fédoroff et al. 2005; Smart et al. 2002).

An increase in the amount of edge habitat can make a fragment more vulnerable to invasion by exotic species and to more extreme abiotic influences (Saunders et al. 1991; Weathers et al. 2001). We do not review abiotic edge effects of habitat fragmentation, such as light intensity, soil moisture, and nutrients (see Saunders et al. 1991; Weathers et al. 2001). Field boundaries, which are one kind of edges in the agricultural landscape, contain more plant species than field centers especially in intensive production farming systems (e.g., Aude et al. 2003; Smart et al. 2002). Thus, habitat fragmentation can enhance biodiversity by increasing field boundary length, as suggested by Debinski and Holt (2000). Moreover, the edge effect is not spatially limited to the edge area; it extends to each side of the edge across a zone of ca. $8 \mathrm{~m}$ (Piessens et al. 2006). The last authors explained this vegetation gradient between edge and fragment core by eutrophication involving higher soil nitrogen content near the field edge than in the fragment core. Fertilization and the decomposition of tree leaves can create such a soil nitrogen gradient (Piessens et al. 2006). However, such a difference of nitrogen fertility in favor of field boundaries is not a general rule in permanent grasslands because application of fertilizers often occurs leading to higher nitrogen fertility in field core than in field boundaries. Other explanations should be the gradient of others abiotic factors induced by field boundaries such as radiation flux, water flux, and wind. The gradients of these last factors have been well reviewed by Saunders et al. (1991) and described in a study case by Walker et al. (2003).

The fate of remnant plant populations within habitat patches depends on the degree of isolation, the quality of the matrix habitat, the size of the remnant population (Soons and Heil 2002), and species characteristics such as mating system, seed dispersal ability, seed bank persistence, and plant longevity (Bruun 2000; Joshi et al. 2006). Habitat fragmentation is not perceived equally by all plant species. For example, plants with less self-pollination ability show reduced population viability in locally fragmented grassland habitats, with pronounced extinction thresholds at certain levels of habitat fragmentation (Lennartsson 2002). Therefore, the third characteristic of landscape configuration, habitat connectivity, is also necessary to understand species composition in permanent grasslands.

Habitat fragmentation can be broken up into two effects: the fragment area and the edge effect (Table 1). Even if large fragment tends in theory to induce greater species richness, the effects of fragment area on vegetation are not homogeneous: they depend on functional properties of plant species. Concerning the edge effect it can enhance biodiversity by increasing the size of field boundaries which can act as sources of species.

\subsection{Habitat connectivity and corridors}

Connectivity is a measure of the ability of organisms to move among separated patches of suitable habitat (Hilty et al. 2006). We must distinguish structural connectivity and functional connectivity of habitats. Structural connectivity is related to landscape pattern and results from the density and complexity of corridors and the matrix structure (Uezu 
et al. 2005). Structural connectivity is not an efficient way to understand species composition in permanent grasslands because it does not take plant species ecology into account, in contrast to functional connectivity. Functional connectivity is defined by the extent to which an individual species can move through a landscape (Uezu et al. 2005). This definition is based on several hypotheses about suitable habitats available in target area for a given species or a given group of species sharing resource requirements. Here, we consider only functional connectivity as defined by Uezu et al. (2005).

\subsubsection{Functional connectivity}

We consider studies dealing with both functional connectivity and habitat isolation, which is the opposite of habitat connectivity. It is widely agreed that connectivity is an important factor for species conservation (Debinski and Holt 2000; Kirchner et al. 2003). Connectivity allows propagule movement among areas for reproduction and gene flow between populations (Hamilton et al. 2006) and avoids isolation of habitats and populations (Fischer and Lindenmayer 2007). Then, by favoring gene flow between distant populations and thus the plant reproductive success, habitat connectivity helps to prevent decreasing plant fitness (Gabriel and Tscharntke 2007; Newman and Tallmon 2001; Piessens et al. 2004). Connectivity has a positive effect on plant species richness in grasslands in Belgium (Piessens et al. 2005; Piessens et al. 2004). Plant species richness increases with increasing connectivity due to increasing colonization rates (Joshi et al. 2006; Maurer et al. 2003; Piessens et al. 2004) and decreasing extinction rates (Pacha and Petit 2008; Piessens et al. 2004) because of higher gene flow (Piessens et al. 2004). Connectivity has a positive effect on the occurrence of a mixed grassland and forest herbaceous species, Geranium sylvaticum L., in grasslands in UK (Pacha and Petit 2008). One study (Eriksson et al. 1995) has found no effect of connectivity on plant species richness in grasslands, with local habitat conditions and fertilization levels being more explanatory. Bruun (2000) has found a negative effect of connectivity on Potentilla erecta (L.) Räusch. in dry grasslands in Denmark. This result can be explained by the preference of $P$. erecta for the damp north-facing side of the studied hill, which is an area with low connectivity.

Thus, habitat connectivity is perceived differently by plant species according to their functional properties, particularly their range of suitable habitats (habitat generalists vs. habitat specialists; Dupré and Ehrlén 2002), mode and mass of propagule dispersal (Soons and Heil 2002) and life history (Bruun 2000). Species richness of long-lived species is not affected by connec- tivity, in contrast to species richness of short-lived species, which is positively correlated with connectivity of Danish dry grasslands (Bruun 2000). We infer that even with low propagule dissemination, long-lived species retain a few individuals in small, unconnected patches due to their life history. Connectivity between two plant populations can be disrupted even at the small scale of $5 \mathrm{~m}$ isolation distance by decreasing colonization rate (Joshi et al. 2006). Species richness of species with shortterm persistent seed banks is more positively affected by connectivity than species richness of species with longterm persistent seed banks (Piessens et al. 2005; Piessens et al. 2004). We hypothesize that species with long-term persistent seeds can maintain a few individuals in a patch even if dispersal is very low. Species with long-term persistent seed banks are less sensitive to extinction, independent of patch area.

\subsubsection{Corridors}

Corridors are areas within a target area that allow movement of a given species from one habitat patch to another. Corridors for plant species include linear landscape elements such as road margins (Soons et al. 2005; Tikka et al. 2001; van Dorp et al. 1997). Such an area may be a corridor for some species and a barrier for others (Hilty et al. 2006). Within a territory, corridors must be defined according to studied species and their functional properties. The efficiency of corridors is not homogeneous in the literature, showing either positive (Cousins and Eriksson 2001; Tikka et al. 2001) or without effects. In particular, corridor had not any effect in a study case of perennial grassland species with short-range seed dispersal in The Netherlands (van Dorp et al. 1997) and in a study of two forbs (Cirsium dissectum (L.) Hill and Succisa pratensis Moench) in nutrient-poor semi-natural grasslands (Soons et al. 2005).

The literature relates three primary explanations about the no efficiency of corridors to improve seed dispersal in farmlands. First, most linear landscape elements are unsuitable for seedling establishment because of high plant productivity and vegetative cover (Soons and Heil 2002; Soons et al. 2005; van Dorp et al. 1997). Second, migration rates within these linear landscape elements are low (van Dorp et al. 1997). Moreover, these elements have low colonization capacity because they produce only a few seeds whose dispersal ability is low as a result of dense vegetative cover (Soons and Heil 2002). Third, the shape (particularly the width) of corridors affects seeds dispersing from them by decreasing the probability of reaching another habitat patch (Soons et al. 2005; van Dorp et al. 1997). For example, migration rates in corridors approximate those in continuous habitats if corridor width exceeds 
$20 \mathrm{~m}$ (van Dorp et al. 1997). It is crucial to consider landscape elements (linear elements and others) according to their suitability for a given species or group of functionally similar species.

Connectivity is a major factor for species conservation, usually in favor to increase species richness. However, habitat connectivity and corridors have different effects according to studied plant species and their functional properties (Table 1): range of suitable habitats, mass of propagules, mode of propagule dispersal, and life history.

\section{Synthesis and conclusion}

As exposed in the Introduction, our aims for this review are (a) to integrate knowledge of plant ecology in permanent grasslands and (b) to identify factors that can be adapted by individual farmers and factors that depend on several farmers within a territory. We have described in this literature review the primary factors that influence plant diversity in permanent grasslands, their effects, and the processes involved. These factors and processes are summarized in Table 1, with major references. We proposed in this last part, firstly, the integration of reviewed knowledge in this paper based on community assembly theory (Belyea 2004; Weiher and Keddy 1999) and a conceptual example on the effects of these factors on species richness. Secondly, we develop applied consequences on the abilities of single farmer to manage plant diversity in its permanent grassland, for example, for dealing with objectives of agri-environmental schemes.

\subsection{Knowledge integration in community assembly theory}

Community assembly theory (Belyea 2004; Weiher and Keddy 1999) provides a useful framework to assess the response of grassland plant communities to field- and landscape-scale factors. Under this framework, grassland plant communities were constrained by abiotic and biotic filters that act on species biological characteristics to determine actual community composition. According to this concept, field- and landscape-scale processes such as dispersal, competition, and regeneration determine how many and which species, from a regional species pool, are "waiting at the entrance and establishment" to a target community, thus forming the actual species pool. The target community is a plant community bound to a certain set of environmental conditions that provide appropriate ecological niches for the occurring species. Unfortunately, in many comparative studies, there has been no filtering of species lists before comparison of richness on different scales, so that it is often impossible to find a significant relationship between large- and small-scale richness (Zobel 1997).

So, we propose a conceptual model (Fig. 8) structuring all of these factors and processes according to the community assembly theory based on three ecological challenges: dispersal, establishment, and persistence (Rosenzweig 1995). We consider each of these challenges to act as a filter that prevents available species in the regional species pool from dispersing into, establish in, or persisting in the target community. The presence of a particular species in the actual species pool is determined by its biological abilities to "successfully complete the three challenges". We describe this species filtering based on processes identified along this review. A given process can act on one or two filters; for example, competitive exclusion constrains the establishment and persistence of plant species (Fig. 8). Similarly, a given process can be generated by several factors; for example, the presence of refuge habitats depends on both landscape heterogeneity and the edge effect. We incorporate the effect of landscape heterogeneity on the regional species pool. A heterogeneous landscape often contains greater habitat diversity and thus greater species richness than a homogeneous one (Rosenzweig 1995). This model can explain the difference in species richness between the regional species pool and actual species pool in permanent grasslands. Field-scale and landscape-scale factors affect all three filters, but only landscape heterogeneity affects the species richness of the regional species pool. Moreover, processes described for landscape-scale factors and processes described for fieldscale factors are different, except competition for a common resource.

Therefore, both groups of factors must be considered to predict the state of permanent grassland vegetation and to develop decision rules for farmers or decision makers to preserve farmland plant diversity. Nevertheless, we have only found five studies which compare the relative influence of landscape- and field-scale factors on grassland vegetation (Dauber et al. 2003; Le Coeur et al. 1997; Marini et al. 2008; Weibull and Östman 2003; Weibull et al. 2003). The results of these studies are not homogeneous. For example, Le Coeur et al. (1997) have found a positive effect of proportions of field boundaries adjacent to grassland and density of hedgerows in the landscape on the species composition of vegetation in hedgerows. Conversely, Marini et al. (2008) and Dauber et al. (2003) have not found effects of landscape characteristics on species richness of permanent grassland vegetation. These differences could be explained by methodological differences. Indeed, it is difficult to compare these results because these five studies did not distinguish the same landscape elements nor use the same landscape indices. Studies often do not consider all influential factors, 


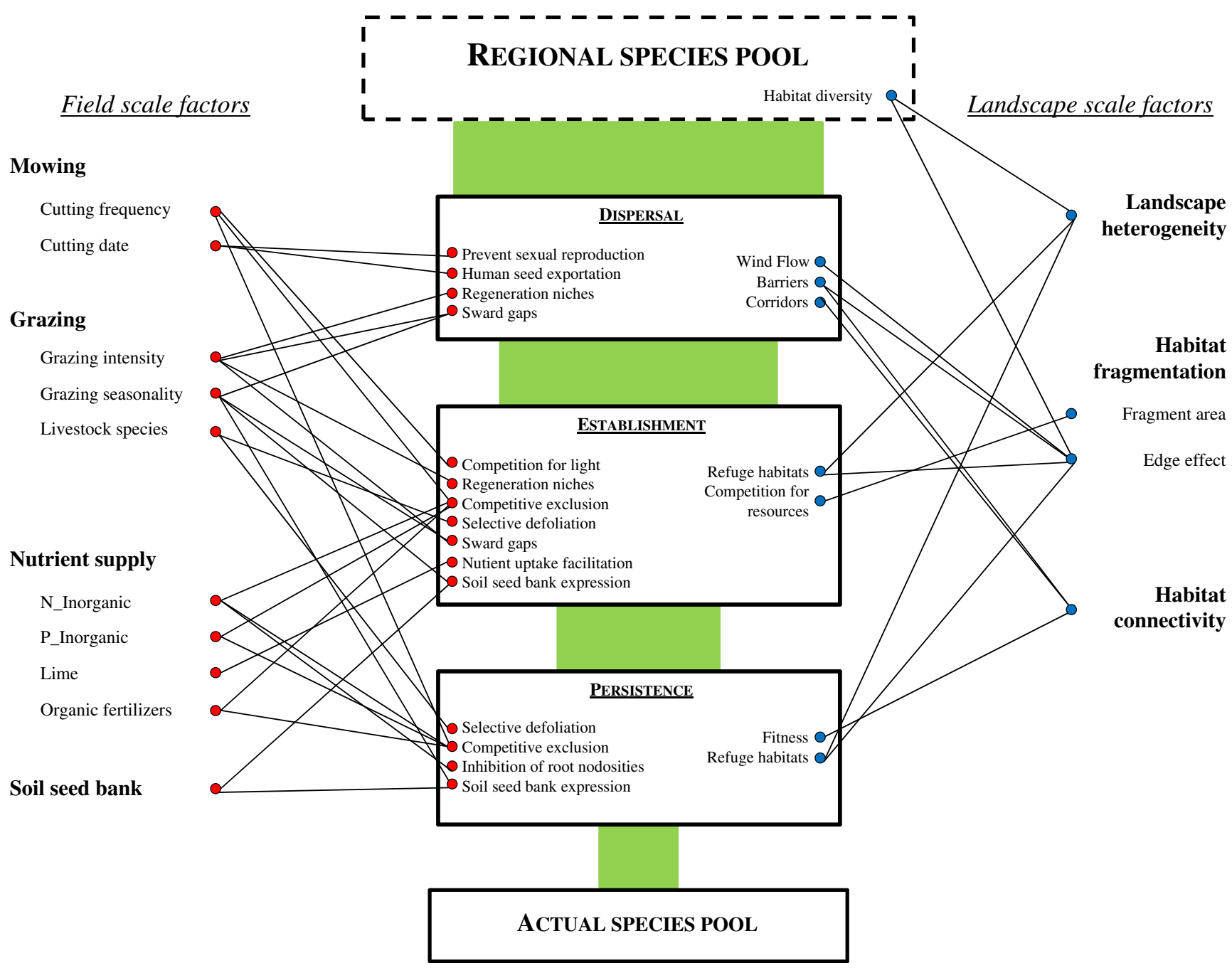

Fig. 8 Conceptual model linking three ecological challenges for permanent grassland plant biodiversity, influential factors, and associated processes. The width of green forms represent the species richness, particularly its decrease between the regional species pool

whatever their scale, possibly leading to mistaken conclusions about the relative influence of the two groups of factors. Two other aspects largely developed in the current review could explain these differences. Firstly, effect of exposed factors depends on functional properties (sensu Violle et al. 2007) of plants. Plant communities studied in these five works could be different because of distinct geographical locations. Secondly, the initial state of grassland vegetation is also primordial to determine the effect of the change of a given factor as we explained for the effect of stocking rate above. These five studies had not the same initial state which can conduct to a bias in the comparison of their results.

In order to take into account this complexity of factors of the currently studied permanent grasslands, we proposed a synthetic scheme for the dynamics of plant species richness based on four parameters: the proportion of plants with and the actual species pool due to the selection operated by each filter which allows or prevent the dissemination, the establishment or the persistence of plant species

high dispersal abilities, the level of disturbance from farming practices, the landscape heterogeneity, and the level of forage productivity of the studied grassland (Fig. 9). In order to build this scheme, we hypothesize that: (a) species richness is higher in grasslands with low forage productivity than in those with high forage productivity (Hector et al. 1999), (b) the regional or actual species pool increases with landscape heterogeneity (Rosenzweig 1995), (c) the initial species richness is higher when the dispersal abilities of species were long-distance dispersal. The dynamic of actual species pool, whatever the landscape heterogeneity, when the disturbances from farming practices were strong, never reach the regional species pool (Fig. 9). The dynamics of the actual species pool can lead to the regional species pool when disturbances from farming practices are weak but depending on the forage productivity level. Indeed, when the forage productivity is 
Fig. 9 Relative increase of species richness in permanent grasslands based on landscape heterogeneity and its dependence on farming-induced disturbance, the dispersal abilities of plant species in the regional species pool and the productivity of grassland (modified from Roschewitz et al. 2005 and Le Roux et al. 2008)
Legend: Species pools :

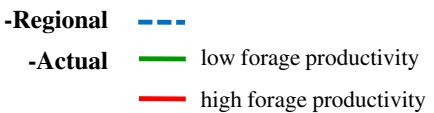

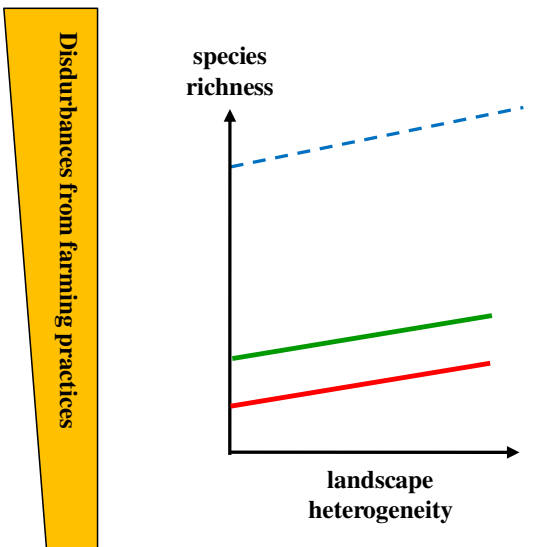

species

richness

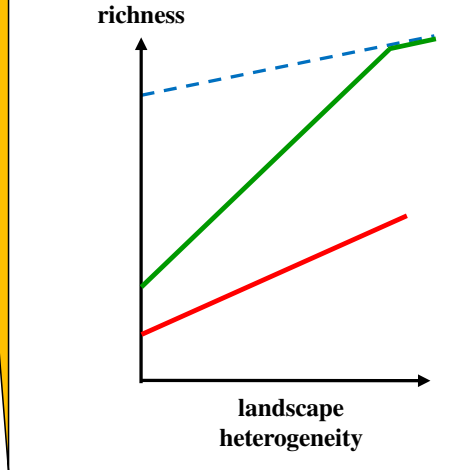

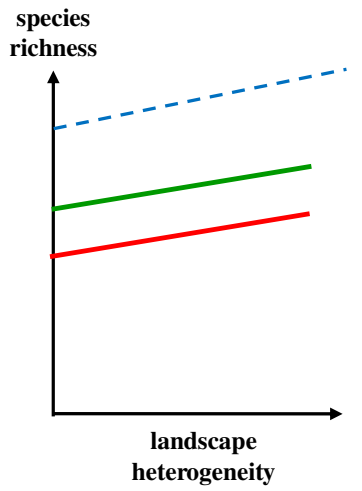

species hnes heterogeneity

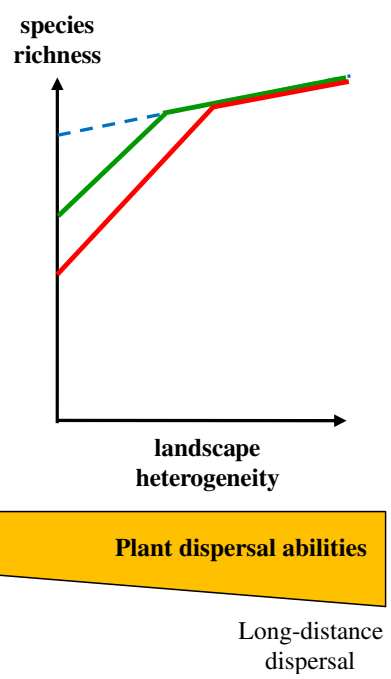

low, the actual species pool could be the same than the regional species pool whatever the plant dispersal abilities (Fig. 9). In this case, the actual species pool can reach the regional species pool with low landscape heterogeneity only if plant community presents high dispersal abilities. In the case of high forage productivity, the regional species is reached only when plant dispersal abilities and landscape heterogeneity were high (Fig. 9). Thus, the influence of increasing landscape heterogeneity on species richness is governed by the level of disturbance induced by farming practices.

This review and the proposed conceptual models explain why it is important to consider both groups of factors and to use both taxonomic and functional approaches. Nevertheless, the farmer managed directly the farming practices and indirectly the landscape heterogeneity by the arrangement of their grasslands in his farm territory.

\subsection{Mobilization of factors by a single farmer}

In order to manage plant diversity in its permanent grasslands, a single farmer cannot mobilize all above presented influent factors (Table 1, Figs. 8 and 9). Without considering induced management problems at farm scale, a single farmer can adapt all field-scale factors expected soil seed bank, in order to achieve a particular objective linked to the field use (spread the productivity period by diversifying plant species composition, increase sward resistance against trampling...). For example, he is free to increase the fertilizer supply or decrease the stocking rate 
on a given grassland, with respect of agricultural laws. However, he cannot totally drive the plant diversity in this grassland because of landscape-scale factors.

These landscape-scale factors-landscape heterogeneity, habitat fragmentation, and habitat connectivity (Table 1, Figs. 8 and 9) - depends on many actors sharing the same territory: farmers, ecological managers, local authorities, road managers... The target farmer is able to change this landscape according to the proportion of the studied territory which he manages. Thus, the driving of plant diversity in a given permanent grassland depends on both the farmer who cultivate a part of grasslands of the studied farmland and all other actors who participate to the landscape building. In particular, all these actors influence the regional species pool through their impact on landscape heterogeneity (Figs. 8 and 9) and then partly control the plant species diversity which can reach target permanent grassland.

This diversity of influent factors on plant diversity of permanent grasslands and their adaptability by a single farmer questions the success of agri-environmental schemes. These schemes are generally adopted by a single farmer for permanent grasslands, with a given objective. However, how to achieve such objective about plant diversity level in permanent grasslands whereas the farmer who contracts such a scheme cannot manage totally all influent factors? This consideration must be taken into account by policy makers who have to consider three aspects for the development of these schemes. The first concerns the determination of the efficient spatial scale: a field, a group of distant fields managed by the same farmer, a group of adjacent fields potentially cultivated by distinct farmers and separated by urban area, and area managed by administrative managers. For reaching a given objective, schemes should be generally contracted by a group of actors in the same territory and not only by a single farmer. In the same way, the second important aspect is the initial state of the studied permanent grasslands, in terms of farming uses (productivity levels for example), taxonomic, and functional characteristics of vegetation. As we show in this review, effects of the different factors, at field scale and at landscape scale, often depend on the initial state of grassland vegetation. The last crucial aspect is the temporal scale: there is a time lag between factor modifications and visible effects on vegetation (Bakker and ter Heerdt 2005). This time lag must also be considered for the elaboration of the agri-environmental schemes and particularly for the controls by authorities. Moreover, this time lag depends on the spatial scale and the initial state of grasslands. For example, the time lag will not be the same if the success of the scheme objective needs dispersion of seeds through a large landscape or tillage practices to plough up seeds contained in soil seed banks of the studied grasslands. Also, the time lag depends on functional properties of vegetation and agri-environmental schemes objectives.

We synthetically illustrate all these constraints on the increase of plant species richness, based on Fig. 9. In this scheme, the single farmer can adapt the level of disturbances from farming practices and partly the landscape heterogeneity. Then, the dynamics of species richness also depends on the initial state of the target grassland considered here as the forage productivity level and the functional properties of species.

We illustrate this complexity of interactions between influent factors by using the stocking rate as the farming disturbance and plant dispersal abilities as influent plant functional property. The increase in species richness with increasing landscape heterogeneity is greater for low than for high stocking rates. High stocking rates prevent the persistence and/or the establishment of several species. This is due to constraints induced by the removal of aerial parts, particularly for annual species with long life cycles that may not have enough time to produce seeds. Moreover, high stocking rates can induce large gaps especially during wet soil conditions. Then, under high stocking rates, the increase of species richness depends primarily on landscape heterogeneity and not on the proportion of plant species in the landscape with long-distance dispersal abilities. In contrast, low-stocking rates create moderate disturbances in plant communities, allowing the establishment and persistence of species that disperse into a field and thus higher increase of species richness than under high stocking rates.

\section{Conclusion}

The understanding and the predicting of plant diversity in permanent grassland need to take into account a large panel of factors, through diversified processes. From our knowledge, we are the first to propose a conceptual scheme based on assembly rules and ecological challenges grouping these factors and involved processes. Such a conceptual scheme should be useful to integrate results from a specific study about a process or the influence of a given factor. It could also be useful to elaborate agri-environment schemes by considering all influent factors and thus all involved actors. We show in this review that a single farmer cannot completely drive, as he wants, plant diversity in its permanent grasslands. Moreover, it is very complex to create support decision tools to farmers or end users because of the diversity of responses of plant communities after changes of one or several of these factors. These responses depend on the initial state of plant communities and functional properties of plants in the community. A functional approach based on plant functional properties 
relative to the three ecological challenges can show the primary filters and processes driving permanent grassland vegetation. The temporal scale is another important point, not dealing with in this review, to study plant community dynamics in permanent grasslands (and also for other plant communities). As explained above, there is often a time lag between factors changes and visible effect on vegetation. This is an additional constraint to develop a support decision tool and to evaluate agri-environmental scheme efficiency. We argue to consider long-term study in order to take into account the dynamics of all driving factors to understand dynamics of plant communities.

Acknowledgments This review was made within the DIVA 2 project (public action, agriculture, and biodiversity) "Design and ownership of agri-environmental measure to obligation of result on pasture: Reconciling agricultural and ecological relevance in public action for biodiversity?" funded by the French Ministry of Food, Agriculture, and Fisheries. We thank the field editor and the reviewer for their comments on the first draft of this manuscript.

\section{References}

Aarons SR, O'Connor CR, Gourley CJP (2004) Dung decomposition in temperate dairy pastures. I. changes in soil chemical properties. Aust J Soil Res 42:107-114. doi:10.1071/SR03008

Adler PB, Raff DA, Lauenroth WK (2001) The effect of grazing on the spatial heterogeneity of vegetation. Oecologia 128:465-479. doi:10.1007/s004420100737

Aerts RJ, McNabb WC, Molan A, Brand A, Barry TN, Peters JS (1999) Condensed tannins from Lotus corniculatus and Lotus pedunculatus exert different effects on the in vitro rumen degradation of ribulose-1, 5-bisphosphate carboxylase/oxygenase (Rubisco) protein. J Sci Food Agric 79:79-85. doi:10.1002/ (SICI)1097-0010(199901)79:1<79::AID-JSFA187>3.0.CO;2-K

Akinola MO, Thompson K, Hillier SH (1998) Development of soil seed banks beneath synthesized meadow communities after seven years of climate manipulation. Seed Sci Res 8:493-500. doi:10.1017/S0960258500004463

Amiaud B, Touzard B (2004) The relationships between soil seed bank, aboveground vegetation and disturbances in old embanked marshlands of Western France. Flora 199:25-35. doi:10.1078/ 0367-2530-00129

Amiaud B, Bouzillé JB, Tournade F, Bonis A (1998) Spatial patterns of soil salinities in old embanked marshlands in western france. Wetlands 18:482-494. doi:10.1007/BF03161540

Ansquer P, Duru M, Theau JP, Cruz P (2009) Convergence in plant traits between species within grassland communities simplifies their monitoring. Ecol Indic 9:1020-1029. doi:10.1016/j. ecolind.2008.12.002

Arnthorsdottir S (1994) Colonization of experimental patches in a mown grassland. Oikos 70:73-79

Aude E, Tybirk K, Bruus Pedersen M (2003) Vegetation diversity of conventional and organic hedgerows in Denmark. Agric Ecosyst Environ 99:135-147. doi:10.1016/S0167-8809(03)00146-4

Bakker JP (1989) Nature management by grazing and cutting. Kluwer, Dordrecht, Boston, London
Bakker JP, Berendse F (1999) Constraints in the restoration of ecological diversity in grassland and heathland communities. Trends Ecol Evol 14:63-68. doi:10.1016/S0169-5347(98)01544-4

Bakker JP, ter Heerdt GN (2005) Organic grassland farming in the Netherlands: a case study of effects on vegetation dynamics. Basic Appl Ecol 6:205-214. doi:10.1016/j.baae.2005.01.003

Balent G, Alard D, Blanfort V, Poudevigne I (1999) Pratiques de gestion, biodiversité floristique et durabilité des prairies. Fourrages 160:385-402

Barbaro L, Dutoit T, Anthelme F, Corcket E (2004) Respective influence of habitat conditions and management regimes on prealpine calcareous grasslands. J Environ Manage 72:261-275. doi:10.1016/j.jenvman.2004.05.006

Barthram GT, Bolton GR, Elston DA (1999) The effects of cutting intensity and neighbour species on plant of Lolium perenne, Poa annua, Poa trivialis and Trifolium repens. Agronomie 19:445456

Baudry J, Burel F, Thenail C, Le Coeur D (2000) A holistic landscape ecological study of the interactions between farming activities and ecological patterns in Brittany, France. Landscape Urban Plan 50:119-128. doi:10.1016/S0169-2046(00)00084-0

Belyea LR (2004) Beyong ecological filters: feedback networks in the assembly and restoration of community structure, p. 115-131. In: Temperton VM, Hobbs R, Nuttle T, Halle S (eds) Assembly rules and restoration ecology. Bridging the gap between theory and practice. Island Press, Washington, pp 115-131

Benton TG, Vickery JA, Wilson JD (2003) Farmland biodiversity: is habitat heterogeneity the key? Trends Ecol Evol 18:182-186. doi:10.1016/S0169-5347(03)00011-9

Bissels S, Donath TW, Holzel N, Otte A (2006) Effects of different mowing regimes on seedling recruitment in alluvial grasslands. Basic Appl Ecol 7:433-442. doi:10.1016/j.baae.2005.10.002

Blackshaw RE, Molnar LJ, Larney FJ (2005) Fertilizer, manure and compost effects on weed growth and competition with winter wheat in western Canada. Crop Prot 24:971-980. doi:10.1016/j. cropro.2005.01.021

Bonischot R (1989) Peut-on faire l'économie de la fertilisation phosphatée sur prairie permanente. Fourrages 118:167-178

Bornard A, Brau-Nogué C (1994) La fertilisation organique en alpage: influence su la qualité et évolution de la végétation. Fourrages 139:367-374

Bruun HH (2000) Patterns of species richness in dry grassland patches in an agricultural landscape. Ecography 23:641-650. doi:10.1111/j.1600-0587.2000.tb00307.x

Bullock JM, Pakeman RJ (1996) Grazing of lowland heath in England: management methods and their effects on heathland vegetation. Biol Conserv 79:1-13. doi:10.1016/S0006-3207(96) 00117-6

Bullock JM, Hill BC, Dale MP, Silvertown J (1994) An experimentalstudy of the effects of sheep grazing on vegetation change in a species-poor grassland and the role of seedlings recruitment into gaps. J Appl Ecol 31:493-507

Bullock JM, Clear HB, Silvertown J, Sutton M (1995) Gap colonisation as a source of grassland community change: effects of gap size and grazing on the rate and mode of colonization by different species. Oikos 72:273-282

Bullock JM, Franklin J, Stevenson MJ, Silvertown J, Coulson SJ, Gregory SJ, Tofts R (2001) A plant trait analysis of responses to grazing in a long-term experiment. J Appl Ecol 38:253-267. doi:10.1046/j.1365-2664.2001.00599.x

Burel F, Baudry J (1999) Ecologie du paysage - concepts, méthodes et applications. Tec\&Doc, Paris

Calladine J, Baines D, Warren P (2002) Effects of reduced grazing on population density and breeding success of black grouse in northern England. J Appl Ecol 39:772-780. doi:10.1046/j.13652664.2002.00753.x 
Carlen C, Darbellay C, Gex P (1998) Effets à long terme de la fumure et de la fréquence des coupes sur une prairie permanente en pontagne. Rev Suisse Agric 30:215-221

Chambers JC (1993) Seed and vegetation dynamics in an alpine herb field: effects of disturbance type. Can J Bot 71:471-485. doi: $10.1139 / \mathrm{b} 93-052$

Chapin FS, Matson PA, Mooney HA (2002) Principles of terrestrial ecosystem ecology. New York, USA

Chee YE (2004) An ecological perspective on the valuation of ecosystem services. Biol Conserv 120:549-565. doi:10.1016/j. biocon.2004.03.028

Connell JH, Slatyer RO (1977) Mechanisms of succession in natural communities and their role in community stability and organization. Am Nat 111:1119-1144

Cop J, Vidrih M, Hacin J (2009) Influence of cutting regime and fertilizer application on the botanical composition, yield and nutritive value of herbage of wet grasslands in Central Europe. Grass Forage Sci 64:454-465. doi:10.1111/j.1365-2494.2009.00713.x

Costanza R, Arge R, de Groot R, Farber S, Grasso M, Hannon B, Limburg K, Naeem S, Oneill RV, Paruelo J, Raskin RG, Sutton P, vanden Belt M (1997) The value of the world's ecosystem services and natural capital. Nature 387:253-260. doi:10.1038/387253a0

Cousins SAO (2006) Plant species richness in midfield islets and road verges - the effect of landscape fragmentation. Biol Conserv 127:500-509. doi:10.1016/j.biocon.2005.09.009

Cousins SAO, Aggemyr E (2008) The influence of field shape, area and surrounding landscape on plant species richness in grazed exfield. Biol Conserv 141:126-135. doi:10.1016/j.biocon.2007.09.004

Cousins SAO, Eriksson O (2001) Plant species occurrences in a rural hemiboreal landscape: effects of remnant habitats, site history, topography and soil. Ecography 24:461-469. doi:10.1111/j.16000587.2001.tb00481.x

Cousins SAO, Ohlson H, Eriksson O (2007) Effects of historical and present fragmentation on plant species diversity in semi-natural grasslands in Swedish rural landscapes. Landscape Ecol 22:723730. doi:10.1007/s10980-006-9067-1

Critchley CNR, Walker KJ, Pywell RF, Stevenson MJ (2007) The contribution of English agri-environment schemes to botanical diversity in arable field margins. Aspects Appl Biol 81:293300

Dai X (2000) Impact of cattle dung deposition on the distribution pattern of plant species in an alvar limestone grassland. J Veg Sci 11:715-724. doi: $10.2307 / 3236578$

Dauber J, Hirsch M, Simmering D, Waldhardt R, Otte A, Wolters V (2003) Landscape structure as an indicator of biodiversity: matrix effects on species richness. Agric Ecosyst Environ 98:321-329. doi:10.1016/S0167-8809(03)00092-6

Debinski DM, Holt RD (2000) A survey and overview of habitat fragmentation experiments. Cons Biol 14:342-355. doi:10.1046/ j.1523-1739.2000.98081.x

Diaz S, Cabido M, Casanoves F (1998) Plant functional traits and environmental filters at a regional scale. J Veg Sci 9:113-122. doi: $10.2307 / 3237229$

Diaz S, Noy-Meir I, Cabido M (2001) Can grazing response of herbaceous plants be predicted from simple vegetative traits? J Appl Ecol 38:497-508. doi:10.1046/j.1365-2664.2001.00635.x

Diaz S, Lavorel S, McIntyre S, Falczuk V, Casanoves F, Milchunas DG, Skarpe C, Rusch G, Sternberg M, Noy-Meir I, Landsberg J, Zhang W, Clark H, Campbelle BD (2007) Plant trait responses to grazing - a global synthesis. Glob Change Biol 13:313-341. doi:10.1111/j.1365-2486.2006.01288.x

Duelli P (1997) Biodiversity evaluation in agricultural landscapes: an approach at two different scales. Agric Ecosyst Environ 62:8191. doi:10.1016/S0167-8809(96)01143-7

Dumont B, Carrère P, D'Hour P (2002) Foraging in patchy grasslands: diet selection by sheep and cattle is affected by the abundance and spatial distribution of preferred species. Anim Res 51:367381. doi:10.1051/animres:2002033

Dumont B, Farrugia A, Garel JP, Bachelard P, Boitier E, Frain M (2009) How does grazing intensity influence the diversity of plants and insects in a species-rich upland grassland on basalt soils? Grass Forage Sci 64:92-105. doi:10.1111/j.1365-2494.2008.00674.x

Dupré C (2000) How to determine a regional species pool: a study in two Swedish regions. Oikos 89:128-136. doi:10.1034/j.16000706.2000.890114.x

Dupré C, Ehrlén J (2002) Habitat configuration, species traits and plant distributions. J Ecol 90:796-805. doi:10.1046/j.13652745.2002.00717.x

Dutoit T, Gerbaud E, Buisson E, Roche P (2003) Dynamique d'une communauté d'adventices dans un champs de céréales créé après le labour d'une prairie semi-naturelle: rôles de la banque de graines permanente. Ecoscience 10:225-235

Dutoit T, Buisson E, Gerbaud E, Roche P, Tatoni T (2007) The status of transitions between cultivated fields and their boundaries: ecotones, ecoclines or edge effect? Acta Oecol 31:127-136. doi:10.1016/j.actao.2006.03.010

Edouard N, Fleurance G, Dumont B, Duncan P (2009) Does sward height affect feeding patch choice and voluntary intake in horses? Appl Anim Behav Sci 119:219-228. doi:10.1016/j. applanim.2009.03.017

Edwards GR, Crawley MJ (1999) Herbivores, seed banks and seedling recruitment in mesic grassland. J Ecol 87:423-435. doi:10.1046/ j.1365-2745.1999.00363.x

Ellenberg H, Weber HE, Düll R, Wirth V, Werner W, Paulißen D (1992) Zeigerwerte von Pflanzen in Mitteleuropa. Verlag Erich Goltze $\mathrm{GmbH} \&$ Co KG, Göttingen

Eriksson A, Eriksson O, Berglund H (1995) Species abundance patterns of plants in swedish semi-natural pastures. Ecography 18:310-317. doi:10.1111/j.1600-0587.1995.tb00133.x

Farina A (2007) Principles and methods in landscape ecology: towards a science of the landscape. Springer, Dordrecht

Fédoroff E, Ponge J-F, Dubs F, Fernandez-Gonzales F, Lavelle P (2005) Small-scale response of plant species to land-use intensification. Agric Ecosyst Environ 105:283-290. doi:10.1016/ j.agee.2004.02.006

Fischer J, Lindenmayer DB (2007) Landscape modification and habitat fragmentation: a synthesis. Glob Ecol Biogeogr 16:265280. doi:10.1111/j.1466-8238.2007.00287.x

Fischer M, Wipf S (2002) Effect of low-intensity grazing on the speciesrich vegetation of traditionally mown subalpine meadows. Biol Conserv 104:1-11. doi:10.1016/S0006-3207(01)00149-5

Fischer M, Rottstock T, Marquard E, Middelhoff C, Roscher C, Temperton V-M, Oelmann Y, Weigelt A (2008) L'expérience de Iéna démontre les avantages de la diversité végétale pour les prairies. Fourrages 195:275-286

Fleurance G, Duncan P, Mallevaud B (2001) Daily intake and the selection of feeding sites by horses in heterogeneous wet grasslands. Anim Res 50:149-156. doi:10.1016/j.applanim.2009.03.017

Fleury P, Fleury P, Jeannin B (1994) Fertilisation organique et propriétés environnementales et agronomiques des prairies de fauche. Fourrages 139:355-366

Forman RTT, Godron M (1981) Landscape ecology. Wiley, New-York

Gabriel D, Tscharntke T (2007) Insect pollinated plants benefits from organic farming. Agric Ecosyst Environ 118:43-48. doi:10.1016/ j.agee.2006.04.005

Gabriel D, Thies C, Tscharntke T (2005) Local diversity of arable weeds increases with landscape complexity. Perspect Plant Ecol Evol Syst 7:85-93. doi:10.1016/j.ppees.2005.04.001

Galka A, Zarzycki J, Kopec M (2005) Effect of different fertilisation regimes on species composition and habitat in a long-term grassland experiment, in: Lillak R, Viiralt R, Linke A, Geherman $\mathrm{V}$ (Eds.) Integrating efficient grassland farming and biodiversity. 
13th International Occasional Symposium of the European Grassland Federation, Tartu, Estonia

Garcia F, Carrère P, Soussana JF, Baumont R (2005) Characterisation by fractal analysis of foraging paths of ewes grazing heterogeneous swards. Appl Anim Behav Sci 93:19-37. doi:10.1016/j. applanim.2005.01.001

Gaujour E, Nerrière A, Mignolet C, Amiaud B, (2009) Landscape pattern dynamics differently affects permanent grassland vegetation according to seed dispersal agent, INTECOL conference, Brisbane, Australia

Geertsema W, Opdam P, Kropff MJ (2002) Plant strategies and agricultural landscape: survival in spatially and temporally fragmented habitat. Landscape Ecol 17:263-279. doi:10.1023/ A: 1020228708956

Gibon A (2005) Managing grassland for production, the environment and the landscape. Challenges at the farm and the landscape level. Livest Prod Sci 96:11-31. doi:10.1016/j.livprodsci. 2005.05.009

Gibson CWD, Brown VK (1991) The effects of grazing on local colonisation and extinction during early succession. J Veg Sci 2:291-300. doi:10.2307/3235919

Gillet F, Kohler F, Vandenberghe C, Buttler A (2010) Effect of dung deposition on small-scale patch structure and seasonal vegetation dynamics in mountain pastures. Agr Ecosyst Environ 135:34-41. doi:10.1016/j.agee.2009.08.006

Gough MW, Marrs RH (1990) A comparison of soil fertility between semi-natural and agricultural plant-communities-implications for the creation of species-rich grassland on abandoned agricultural land. Biol Conserv 51:83-96. doi:10.1016/0006-3207(90) 90104-W

Gough L, Osenberg CW, Gross KL, Collins SL (2000) Fertilization effects on species density and primary productivity in herbaceous plant communities. Oikos 89:428-439. doi:10.1034/j.16000706.2000.890302.x

Grime JP (1979) Plant strategies and vegetation processes. Wiley, Chichester

Grime JP, Hodgson JG, Hunt R (1988) Comparative plant ecology-A functional approach to common British species. Chapman \& Hall, Ipswich, Suffolk

Grubb PJ (1977) The maintenance of species-richness in plant communities: the importance of the regeneration niche. Biol Rev 52:107-145. doi:10.1111/j.1469-185X.1977.tb01347.x

Gu W, Heikkilä R, Hanski I (2002) Estimating the consequences of habitat fragmentation on extinction risk in dynamic landscapes. Landscape Ecol 17:699-710. doi:10.1023/A:1022993317717

Hamilton GS, Mather PB, Wilson JC (2006) Habitat heterogeneity influences connectivity in a spatially structured pest population. $\mathrm{J}$ Appl Ecol 43:219-226. doi:10.1111/j.1365-2664.2006.01132.x

Hatch DJ, Lovell RD, Antil RS, Jarvis SC, Owen PM (2000) Nitrogen mineralization and microbial activity in permanent pastures amended with nitrogen fertilizer or dung. Biol Fertil Soils 30:288-293. doi:10.1007/s003740050005

Hector A, Schmid B, Beierkuhnlein C, Caldeira MC, Diemer M, Dimitrakopoulos PG, Finn JA, Freitas H, Giller PS, Good J, Harris R, Högberg P, Huss-Danell K, Joshi J, Jumpponen A, Körner C, Leadley PW, Loreau M, Minns A, Mulder CPH, O’Donovan G, Otway SJ, Pereira JS, Prinz A, Read DJ, SchererLorenzen M, Schulze E-D, Siamantziouras A-SD, Spehn EM, Terry AC, Troumbis AY, Woodward FI, Yachi S, Lawton JH (1999) Plant diversity and productivity experiments in European grasslands. Science 286:1123-1127. doi:10.1126/science.286.5442.1123

Hector A, Hautier Y, Saner P, Wacker L, Bagchi R, Joshi J, SchererLorenzen M, Spehn EM, Bazeley-White E, Weilenmann M, Caldeira MC, Dimitrakopoulos PG, Finn JA, Huss-Danell K, Jumpponen A, Mulder CP, Palmborg C, Pereira JS, Siamantziouras ASD, Terry AC, Troumbis AY, Schmid B, Loreau M (2010) General stabilizing effects of plant diversity on grassland productivity through population asynchrony and overyielding. Ecol 91:22132220. doi:10.1890/09-1162.1

Hejcman M, Klaudisova M, Schellberg J, Honsova D (2007a) The Rengen grassland experiment: plant species composition after 64 years of fertilizer application. Agr Ecosyst Environ 122:259 266. doi:10.1016/j.agee.2006.12.036

Hejcman M, Klaudisova M, Stursa J, Pavlu V, Schellberg J, Hejcmanova P, Hakl J, Rauch O, Vacek S (2007b) Revisiting a 37 years abandoned fertilizer experiment on Nardus grassland in the Czech Republic. Agr Ecosyst Environ 118:231-236. doi:10.1016/j.agee.2006.05.027

Hickman KR, Hartnett DC, Cochran RC, Owensby CE (2004) Grazing management effects on plant species diversity in tallgrass prairie. J Range Manage 57:58-65. doi:10.2111/15515028(2004)057[0058:GMEOPS]2.0.CO;2

Hilty JA, Lidicker WZ, Merenlender AM (2006) Corridor ecology. The science and practice of linking landscape for biodiversity conservation. Island Press, Washington

Hopkins WG (2003) Physiologie végétale. De Boeck edition, Bruxelles, p 514

Huntly N (1991) Herbivores and the dynamics of communities and ecosystems. Annu Rev Ecol Syst 22:477-503. doi:10.1146/ annurev.es.22.110191.002401

Illius AW, Gordon IJ (1993) Diet selection in mammalian herbivores — constraints and tactics, p. 369-392 Diet selection. In: Hughes $\mathrm{RN}$ (ed) Diet selection: an interdisciplinary approach to foraging behaviour. Blackwell Scientific Publications, Oxford, pp 157181

Ingvarsson PK (2001) Restoration of genetic variation lost - the genetic rescue hypothesis. Trends Ecol Evol 16:62-63. doi:10.1016/S0169-5347(00)02065-6

Jacquemyn H, Brys R, Hermy M (2003) Short-term effects of different management regimes on the response of calcareous grassland vegetation to increased nitrogen. Biol Conserv 111:137-147. doi:10.1016/S0006-3207(02)00256-2

Janssens F, Peeters A, Tallowin JRB, Bakker JP, Bekker RM, Fillat F, Oomes MJM (1998) Relationship between soil chemical factors and grassland diversity. Plant Soil 202:69-78. doi:10.1023/ A:1004389614865

Johnson AR, Milne BT, Wiens JA (1992) Diffusion in fractal landscapes - simulations and experimental studies of tenebrionid beetle movements. Ecology 73:1968-1983. doi:10.2307/1941448

Joshi J, Stoll P, Rusterholz H-P, Schmid B, Dolt C, Baur B (2006) Small-scale experimental habitat fragmentation reduces colonization rates in species-rich grasslands. Oecologia 148:144-152. doi:10.1007/s00442-005-0341-8

Kahmen S, Poschlod P (2008) Effects of grassland management on plant functional trait composition. Agr Ecosyst Environ 128:137145. doi:10.1016/j.agee.2008.05.016

Kalamees R, Zobel M (2002) The role of the seed bank in gap regeneration in a calcareous grassland community. Ecology 83:1017-1025. doi:10.1890/0012-9658(2002)083[1017: TROTSB]2.0.CO;2

King TJ (2007) The roles of seed mass and persistent seed banks in gap colonisation in grassland. Plant Ecol 193:233-239. doi:10.1007/s11258-006-9261-x

Kirchner F, Ferdy J-B, Andalo C, Colas B, Moret J (2003) Role of corridors in plant dispersal: an example with the endangered Ranunculus nodiflorus. Conserv Biol 17:401-410. doi:10.1046/ j.1523-1739.2003.01392.x

Kirkham FW, Tallowin JRB, Sanderson RA, Bhogal A, Chambers BJ, Stevens DP (2008) The impact of organic and inorganic fertilizers and lime on the species-richness and plant functional characteristics of hay meadow communities. Biol Conserv 141:1411-1427. doi:10.1016/j.biocon.2008.03.010 
Kleijn D, Snoeijing GIJ (1997) Field boundary vegetation and the effects of agrochemical drift: botanical change caused by low levels of herbicide and fertilizer. J Appl Ecol 34:1413-1425

Kleijn D, Sutherland WJ (2003) How effective are European agrienvironment schemes in conservative and promoting biodiversity? J Appl Ecol 40:947-969. doi:10.1111/j.1365-2664.2003.00868.x

Kohler F, Gillet F, Gobat JM, Biuttler A (2004) Seasonal vegetation changes in mountain pastures due to simulated effects of cattle grazing. J Veg Sci 15:143-150. doi:10.1111/j.1654-1103.2004.tb02249.x

Kotanen PM (1997) Effects of gap area and shape on recolonization by grassland plants with differing reproductive strategies. Can J Bot 75:352-361. doi:10.1139/b97-037

Krauss J, Klien A-M, Steffan-Dewenter I, Tscharntke T (2004) Effects of habitat area, isolation, and landscape diversity on plant species richness of calcareous grasslands. Biodivers Conserv 13:14271439. doi:10.1023/B:BIOC.0000021323.18165.58

Kruess A, Tscharntke T (2002) Contrasting responses of plant and insect diversity to variation in grazing intensity. Biol Conserv 106:293-302. doi:10.1016/S0006-3207(01)00255-5

Kull K, Zobel M (1991) High species richness in an Estonian wooded meadow. J Veg Sci 2:711-714. doi:10.2307/3236182

Laissus R, Leconte D (1982) Répercussions de l'épandage de lisier de bovins sur une prairie pâturée. Fourrages 89:63-72

Laissus R, Marty P (1969) Rendements et possibilités d'évolution d'une prairie permanente médiocre soumise à diverses fumures azotées. Fourrages 40:3-21

Lavorel S, Lepart J, Debussche M, Lebreton JD, Beffy JL (1994) Small scale disturbances and the maintenance of species diversity in Mediterranean old fields. Oikos 70:455-473

Le Coeur D, Baudry J, Burel F (1997) Fields margins plant assemblages: variation partitioning between local and landscape factors. Landscape Urban Plan 37:57-71. doi:10.1016/S01692046(96)00370-2

Lennartsson T (2002) Extinction thresholds and disrupted plant-pollinator interactions in fragmented plant populations. Ecology 83:3060 3072. doi:10.1890/0012-9658(2002)083[3060:ETADPP]2.0.CO;2

Le Roux R, Barbault J, Baudry J, Burel F, Doussan I, Garnier E, Herzog F, Lavorel S, Lifran R, Roger-Estrade J, Sarthou JP, Trommetter M (éditeurs) (2008) Agriculture et biodiversité, valoriser les synergies. Expertise scientifique collective, synthèse du rapport, INRA (France)

Lopez-Mariño A, Luis-Calabuig E, Fillat F, Bermudez FF (2000) Floristic composition of established vegetation and the soil seed bank in pasture communities under different traditional management regimes. Agric Ecosyst Environ 78:273-282. doi:10.1016/ S0167-8809(99)00137-1

Loreau M, Naeem S, Inchausti P, Bengtsson J, Grime JP, Hector A, Hooper DU, Huston MA, Raffaelli D, Schmid B, Tilman D, Wardle DA (2001) Biodiversity and ecosystem functioning: current knowledge and future challenges. Science 294:804-808. doi: $10.1126 /$ science. 1064088

Louault F, Pillar VD, Aufrere J, Garnier E, Soussana JF (2005) Plant traits and functional types in response to reduced disturbance in a semi-natural grassland. J Veg Sci 16:151-160. doi:10.1111/ j.1654-1103.2005.tb02350.x

Loucougaray G, Bonis A, Bouzillé J-B (2004) Effects of grazing by horses and/or cattle on the diversity of coastal grasslands in western France. Biol Conserv 116:59-71. doi:10.1016/S00063207(03)00177-0

MacArthur RH, Wilson EO (1967) The theory of island biogeography. Princeton, Oxfordshire

Malo JE, Suarez F (1995) Establishment of pasture species on cattle dung: the role of endozoochorous seeds. J Veg Sci 6:169-174. doi: $10.2307 / 3236211$

Marini L, Fontana P, Scotton M, Klimek S (2008) Vascular plant and Orthoptera diversity in relation to grassland management and landscape composition in the European Alps. J Appl Ecol 45:361-370. doi:10.1111/j.1365-2664.2007.01402.x

Marshall EJP, Arnold GM (1995) Factors affecting field weed and field margin flora on a farm in Essex, UK. Landscape Urban Plan 31:205-216. doi:10.1016/0169-2046(94)01047-C

Martinkova Z, Honek A, Pekar S (2009a) Seed availability and gap size influence seedling emergence of dandelion (Taraxacum officinale) in grasslands. Grass Forage Sci 64:160-168. doi:10.1111/j.1365-2494.2009.00679.x

Martinkova Z, Honek A, Pekar S, Strobach J (2009b) Survival of Rumex obtusifolius L. in an unmanaged grassland. Plant Ecol 205:105-111. doi:10.1007/s11258-009-9601-8

Marusca T, Mocanu V, Blaj V, Hermenean I (2007) Systems for improvement of Nardus stricta subalpine grasslands from Carpathian Mountains, In: Permanent and temporary grassland: plant, environment and economy. Proceedings of the 14th Symposium of the European Grassland Federation, 3-7 September, Ghent, Belgium

Maurer K, Durka W, Stöcklin J (2003) Frequency of plant species in remnants of calcareous grassland and their dispersal and persistence characteristics. Basic Appl Ecol 4:307-316. doi:10.1078/1439-1791-00162

McGarigal K, Marks JB (1995) Fragstats: spatial analysis program for quantifying landscape structure. Gen. Tech. Rep. PNW-GTR351, Portland, OR: US Department of Agriculture, Forest Service, Pacific Northwest Research Station

McIntyre S, Lavorel S, Tremont RM (1995) Plant life-history attributes: their relationship to disturbance response in herbaceous vegetation. J Ecol 83:31-44

Ménard C, Duncan P, Fleurance G, Georges J-Y, Lilas M (2002) Comparative foraging and nutrition of horses and cattle in European wetlands. J Appl Ecol 39:120-133. doi:10.1046/ j.1365-2664.2002.00693.x

Milberg P (1993) Seed bank and sedlings emerging after soil disturbance in a wet semi-natural grassland in Sweden. Ann Bot Fenn 30:9-13

Nathan R, Muller-Landau HC (2000) Spatial patterns of seed dispersal, their determinants and consequences for recruitments. Trends Ecol Evol 15:278-285. doi:10.1016/S0169-5347(00) 01874-7

Newman D, Tallmon DA (2001) Experimental evidence for beneficial fitness effects of gene flow in recently isolated populations. Conserv Biol 15:1054-1063. doi:10.1046/j.15231739.2001.0150041054.x

Nilsson MC, Wardle DA, Zackrisson O, Jaderlund A (2002) Effects of alleviation of ecological stresses on an alpine tundra community over an eight-year period. Oikos 97:3-17. doi:10.1034/j.16000706.2002.970101.x

Olivan M, Osoro K (1997) Use of the $N$-alkane technique to study intake and diet selection by grazing ruminants: a review. ITEA Prod Anim 94a:109-124

Olofsson J, Kitti H, Rautiainen P, Stark P, Oksanen L (2001) Effects of summer grazing by reindeer on composition of vegetation, productivity and nitrogen cycling. Ecography 24:13-24. doi:10.1034/j.1600-0587.2001.240103.x

Öster M, Cousins SAO, Eriksson O (2007) Size and heterogeneity rather than landscape context determine plant species richness in semi-natural grasslands. J Veg Sci 18:859-868. doi:10.1111/ j.1654-1103.2007.tb02602.x

Ozinga WA, Schaminée JHJ, Bekker RM, Bonn S, Poschlod P, Tackenberg O, Bakker JP, Groenendael JMV (2005) Predictability of plant species composition from environmental conditions is constrained by dispersal limitation. Oikos 108:555-561. doi:10.1111/j.0030-1299.2005.13632.x

Pacha MJ, Petit S (2008) The effect of landscape structure and habitat quality on the occurrence of Geranium sylvaticum in fragmented 
hay meadows. Agric Ecosyst Environ 123:81-87. doi:10.1016/j. agee.2007.05.002

Pakeman RJ (2004) Consistency of plant species and trait responses to grazing along a productivity gradient: a multi-site analysis. J Ecol 92:893-905. doi:10.1111/j.0022-0477.2004.00928.x

Palmer SCF, Gordon IJ, Hester AJ, Pakeman RJ (2004) Introducing spatial grazing impacts into the prediction of moorland vegetation dynamics. Landscape Ecol 19:817-827. doi:10.1007/ s10980-005-0094-0

Panos BJ, Silander JA (1992) Seedling recruitment limitation in white clover (Trifolium repens; Leguminosae). Am J Bot 79:643-649

Pautheney Y, Roumet J-P, Neyroz A (1994) Influence de la fertilisation azotée sur la végétation de prairies de fauche en vallée d'Aoste (Italie). Fourrages 139:375-378

Pavlu V, Hejcman M, Pavlu L, Gaisler J, Hejcmanova-Nezerkova P, Meneses L (2006) Changes in plant densities in a mesic speciesrich grassland after imposing different grazing management treatments. Grass Forage Sci 61:42-51. doi:10.1111/j.13652494.2006.00506.x

Pavlu V, Hejcman M, Pavlu L, Gaisler J (2007) Restoration of grazing management and its effect on vegetation in an upland grassland. Appl Veg Sci 10:375-382. doi:10.1111/j.1654-109X.2007. tb00436.x

Peco B, Espigares T, Levassor C (1998) Trends and fluctuations in species abundance and richness in Mediterranean annual pastures. Appl Veg Sci 1:21-28. doi:10.2307/1479082

Piessens K, Honnay O, Nackaerts K, Hermy M (2004) Plant species richness and composition of heathland relics in north-western Belgium: evidence for a rescue-effect? J Biogeogr 31:16831692. doi:10.1111/j.1365-2699.2004.01056.x

Piessens K, Honnay O, Hermy M (2005) The role of fragment area and isolation in the conservation of heathland species. Biol Conserv 122:61-69. doi:10.1016/j.biocon.2004.05.023

Piessens K, Honnay O, Devlaeminck R, Mermy M (2006) Biotic and abiotic edge effects in highly fragmented heathlands adjacent to cropland and forest. Agric Ecosyst Environ 114:335-342. doi:10.1016/j.agee.2005.11.016

Pimm SL (2002) Food webs. University of Chicago Press, Chicago

Pratt RM, Putman RJ, Ekins JR, Edwards PJ (1986) Use of habitat by free-ranging cattle and ponies in the New Forest, Southern England. J Appl Ecol 23:539-557

Rahman KS, Nicholson KS, Wardle DA (1993) Effect of herbicides and fertilisers on ragwort (Senecio jacobaea L.) in hill country pastures, in: New Zealand Grassland Association (Ed.), Proceedings of the XVII International Grassland Congress, Palmerston North, New Zealand

Rajaniemi TK (2002) Why does fertilization reduce plant species diversity? Testing three competition-based hypotheses. J Appl Ecol 90:316-324. doi:10.1046/j.1365-2745.2001.00662.x

Rapp JK, Rabinowitz D (1985) Colonisation and establishment of Missouri prairie plants on artificial soil disturbances. I. Dynamics of forb and graminoid seedlings and shoots. Am J Bot 72:16181628

Reid WV, Mooney HA, Cropper A, Capistrano D, Carpenter SR, Chopra K, Dasgupta P, Dietz T, Duraiappah AK, Hassan R, Kasperson R, Leemans R, May RM, McMichael AJ, Pingali P, Samper C, Scholes R, Watson RT, Zakri AH, Shidong Z, Ash NJ, Benett E, Kumar P, Lee MJ, Raudsepp-Hearne C, Simons H, Thoell J, Zurek NB (2005) Millennium ecosystem assessment synthesis report

Reidsma P, Tekelenburg T, Berg MVD, Alkemade R (2006) Impacts of land-use change on biodiversity: an assessment of agricultural biodiversity in the European Union. Agric Ecosyst Environ 114:86-102. doi:10.1016/j.agee.2005.11.026

Rew LJ, Froud-Williams RJ, Boatman ND (1996) Dispersal of Bromus sterilis and Anthriscus sylvestris seed within arable field margins. Agric Ecosyst Environ 59:107-114. doi:10.1016/01678809(96)01038-9

Rice CK, Stritzke JF (1989) Effects of 2, 4 D and atrazine on degraded Oklahoma grasslands. J Range Manage 42:217-222

Rook AJ, Tallowin JRB (2003) Grazing and pasture management for biodiversity benefit. Anim Res 52:181-189. doi:10.1051/ animres:2003014

Rook AJ, Dumont B, Isselstein J, Osoro K, WallisDeVries MF, Parente G, Mills J (2004) Matching type of livestock to desired biodiversity outcomes in pastures - a review. Biol Conserv 119:137-150. doi:10.1016/j.biocon.2003.11.010

Roscher C, Temperton VM, Scherer-Lorenzen M, Schmitz M, Schumacher J, Schmid B, Buchmann N, Weisser WW, Schulze ED (2005) Overyielding in experimental grassland communitiesirrespective of species pool or spatial scale. Ecol Lett 8:419-429. doi:10.1111/j.1461-0248.2005.00736.x

Roscher C, Bessler H, Oelmann Y, Engels C, Wilcke W, Schulze ED (2009) Resources, recruitment limitation and invader species identity determine pattern of spontaneous invasion in experimental grasslands. J Ecol 97:32-47. doi:10.1111/j.1365-2745.2008.01451.x

Roschewitz I, Gabriel D, Tscharntke T, Thies C (2005) The effects of landscape complexity on arable weed species diversity in organic and conventional farming. J Appl Ecol 42:873-882. doi:10.1111/ j.1365-2664.2005.01072.x

Rosenzweig ML (1995) Species diversity in space and time, Cambridge

Sanderson MA, Goslee SC, Soder KJ, Skinner RH, Tracy BF, Deak A (2007) Plant species diversity, ecosystem function, and pasture management - a perspective. Can J Plant Sci 87:479-487. doi:10.4141/P06-135

Saunders DA, Hobbs RJ, Margules CR (1991) Biological consequences of ecosystem fragmentation: a review. Conserv Biol 5:18-32. doi:10.1111/j.1523-1739.1991.tb00384.x

Schellberg J, Moseler BM, Kuhbauch W, Rademacher IF (1999) Long-term effects of fertilizer on soil nutrient concentration, yield, forage quality and floristic composition of a hay meadow in the Eifel mountains, Germany. Grass Forage Sci 54:195-207. doi:10.1046/j.1365-2494.1999.00166.x

Schippers P, Joenje W (2002) Modelling the effect of fertilizer, mowing, disturbance and width on the biodiversity of plant communities of field boundaries. Agric Ecosyst Environ 93:351365. doi:10.1016/S0167-8809(01)00339-5

Selinger-Looten R, Muller S (2001) Restauration d'un couvert prairial sur ancienne culture de maïs: impact de la fauche et rôle de la banque de graines du sol. Rev Ecologie 56:3-19

Shannon C, Weaver W (1949) The mathematical theory of communication. University of Illinois, Urbana

Sheley R (2007) Tolerance of meadow foxtail (Alopecurus pratensis L.) to two sulfonylurea herbicides. Weed Technol 21:470-472. doi:10.1614/WT-06-063.1

Shiyomi M, Okada M, Takahashi S, Yanhong T (1998) Spatial pattern changes in aboveground plant biomass in a grazing pasture. Ecol Res 13:313-322. doi:10.1046/j.1440-1703.1998.00266.x

Shumway SW, Bertness MD (1994) Patch size effects on marsh plant secondary succession mechanisms. Ecology 75:564-568. doi:10.2307/1939559

Silvertown J, Smith B (1989) Mapping the environment for seed germination in the field. Ann Bot 63:163-167

Smart SM, Bunce RGH, Firbank LG, Coward P (2002) Do field boundaries act as refugia for grassland plant species diversity in intensively managed agricultural landscape in Britain? Agric Ecosyst Environ 91:73-87. doi:10.1016/S0167-8809(01)00259-6

Smith LM, Haukos DA (2002) Floral diversity in relation to playa wetland area and watershed disturbance, Conserv Biol 16:964 974. doi:10.1046/j.1523-1739.2002.00561.x

Smith RS, Buckingham H, Bullard MJ, Shiel RS, Younger A (1996) The conservation management of mesotrophic (meadow) grass- 
land in northern England. 1. Effects of grazing, cutting date and fertilizer on the vegetation of a traditionally managed sward. Grass Forage Sci 51:278-291. doi:10.1111/j.1365-2494.1996.tb02063.x

Smith RS, Shiel RS, Millwards D, Corkhill P, Sanderson RA (2002) Soil seed banks and the effects of meadow management on vegetation change in a 10-year meadow field trial. J Appl Ecol 39:279-293. doi:10.1046/j.1365-2664.2002.00715.x

Söderström B, Svensson B, Vessby K, Glismskär A (2001) Plants, insects and birds in semi-natural pastures in relation to local habitat and landscape factors. Biodivers Conserv 10:1839-1863. doi:10.1023/A:1013153427422

Soons MB, Heil GW (2002) Reduced colonization capacity in fragmented populations of wind-dispersed grassland forbs. J Ecol 90:1033-1043. doi:10.1046/j.1365-2745.2002.00729.x

Soons MB, Messelink JH, Jongejans E, Heil GW (2005) Habitat fragmentation reduces grassland connectivity for both shortdistance and long-distance wind-dispersed forbs. J Ecol 93:1214 1225. doi:10.1111/j.1365-2745.2005.01064.x

Spangenberg JH, Settele J (2010) Precisely incorrect? Monetising the value of ecosystem services. International workshop on ecosystems services - solution for problems of a problem that needs solution, May 2008, Salzau (Germany). Ecol Complex 7:327337. doi:10.1016/j.ecocom.2010.04.007

Spiegelberger T, Hegg O, Matthies D, Hedlund K, Schaffner U (2006) Long-term effects of short-term perturbation in a subalpine grassland. Ecology 87:1933-1944. doi:10.1890/0012-9658 (2006)87[1939:LEOSPI]2.0.CO;2

Stammel B, Kiehl K, Pfadenhauer J (2003) Alternative management on fens: response of vegetation to grazing and mowing. Appl Veg Sci 6:245-254. doi:10.1111/j.1654-109X.2003.tb00585.x

Sternberg M, Gutman M, Perevolotsky A, Ungar ED, Kigel J (2000) Vegetation response to grazing management in a Mediterranean herbaceous community: a functional group approach. J Appl Ecol 37:224-237. doi:10.1046/j.1365-2664.2000.00491.x

Stevens MHH, Bunker DE, Schnitzer SA, Carson WP (2004) Establishment limitation reduces species recruitment and species richness as soil resources rise. J Ecol 92:339-347. doi:10.1111/ j.0022-0477.2004.00866.x

Strykstra RJ, Bekker RM, Verweij GL (1996) Establishment of Rhinanthus angustifolius in a successional hayfield after seed dispersal by mowing machinery. Acta Bot Neerl 45:557-562

Strykstra RJ, Verweij GL, Bakker JP (1997) Seed dispersal by mowing machinery in a Dutch brook valley system. Acta Bot Neerl 46:387-402

Tallowin JRB, Brookman SKE (1996) The impact of differences in nitrogen content utilization and loss from laminae on competition between four grasses species in an old pasture. J Agric Sci $126: 25-35$

ter Heerdt GNJ, Schutter A, Bakker JP (1999) The effect of water supply on seed-bank analysing using the seedling-emergence method. Funct Ecol 13:428-430. doi:10.1046/j.13652435.1999.00329.x

Thompson K, Grime JP (1979) Seasonal variation in the seed banks of herbaceous species in ten contrasting habitats. J Ecol 67:893-921

Thompson K, Ceriani RM, Bakker JP, Bekker RM (2003) Are seed dormancy and persistence in soil related? Seed Sci Res 13:97100. doi:10.1079/SSR2003128

Tikka PM, Högmander H, Koski PS (2001) Road and railway verges serve as dispersal corridors for grassland plants. Landscape Ecol 16:659-666. doi:10.1023/A:1013120529382

Tilman D, Downing JA (1994) Biodiversity and stability in grasslands. Nature 367:363-365. doi:10.1038/367363a0

Tilman D, Wedin D, Knops J (1996) Productivity and sustainability influenced by biodiversity in grassland ecosystems. Nature 379:718-720. doi:10.1038/379718a0
Tilman D, Fargione J, Wolff B, D'Antonio C, Dobson A, Howarth R, Schindler D, Schlesinger WH, Simberloff D, Swackhamer D (2001) Forecasting agriculturally driven global environmental change. Science 292:281-284. doi:10.1126/science.1057544

Touzard B, Amiaud B, Langlois E, Lemauviel S, Clément B (2002) The relationships between soil seed bank, aboveground vegetation and disturbances in an eutrophic alluvial wetland of Western France. Flora 197:175-185. doi:10.1078/0367-2530-00029

Tunnell SJ, Stubbendieck J, Palazzolo S, Masters RA (2006) Forb responses to herbicides in a degraded tallgrass prairie. Nat Areas J 26:72-77. doi:10.3375/0885-8608(2006)26[72:FRTHIA]2.0. $\mathrm{CO} ; 2$

Tzialla CE, Papakosta D, Veresoglou DS (2002) Effects of liming and $\mathrm{N}$ addition on vegetation productivity and species composition in three management systems, in: Durand JL, Huyghe C, Lemaire G (Eds.), Multi-function grasslands: quality forages, animal products and landscapes. 19th General Meeting of the European Grassland Federation, La Rochelle, France, pp. 856857

Uezu A, Metzger J-P, Vieillard JME (2005) Effects of structural and functional connectivity and patch size on the abundance of seven Atlantic forest bird species. Biol Conserv 123:507-519. doi:10.1016/j.biocon.2005.01.001

van der Wal A, Geerts RHEM, Korevaar H, Schouten AJ, Jagers op Akkerhuis GAJM, Rutgers M, Mulder C (2009) Dissimilar response of plant and soil biota communities to long-term nutrient addition in grasslands, Biol. Fert. Soils 45, 663-667. doi:10.1007/s00374-009-0371-1

van Dorp D, Schippers P, van Groenendael JM (1997) Migration rates of grassland plants along corridors in fragmented landscapes assessed with a cellular automation model. Landscape Ecol 12:39-50. doi:10.1007/BF02698206

van Elsen T (2000) Species diversity as a task for organic agriculture in Europe. Agric Ecosyst Environ 77:101-109. doi:10.1016/ S0167-8809(99)00096-1

van Geert A, van Rossum F, Triest L (2010) Do linear landscape elements in farmland act as biological corridors for pollen dispersal. J Ecol 98:178-187. doi:10.1111/j.13652745.2009.01600.x

Violle C, Navas M-L, Vile D, Kazakou H, Fortunel C, Hummel I, Garnier E (2007) Let the concept of trait be functional. Oikos 116:882-892. doi:10.1111/j.0030-1299.2007.15559.x

Vittoz P, Engler R (2007) Seed dispersal distances: a typology based on dispersal modes and plant traits. Bot Helv 117:109-124. doi:10.1007/s00035-007-0797-8

Wagner HH, Edwards PJ (2001) Quantifying habitat specificity to assess the contribution of a patch to species richness at a landscape scale. Landscape Ecol 16:121-131. doi:10.1023/ A:1011118007670

Waldhardt R, Simmering D, Otte A (2004) Estimation and prediction of plant species richness in a mosaic landscape. Landscape Ecol 19:211-226. doi:10.1023/B:LAND.0000021722.08588.58

Walker S, Wilson JB, Steel JB, Rapson GL, Smith B, King WM, Cottam YH (2003) Properties of ecotones: evidence from five ecotones objectively determined from a coastal vegetation gradient. J Veg Sci 14:579-590. doi:10.1111/j.1654-1103.2003.tb02185.x

Wallace LL (1987) Effects of clipping and soil compaction on growth, morphology, and mycorrhizal colonization of Schizachyrium scoparium, a $\mathrm{C}_{4}$ bunch grass. Oecologia 72:423-428. doi:10.1007/BF00377574

WallisDeVries MF (1998) Habitat quality and the performance of large herbivores. In: WallisDeVries MF, Bakker JP, Van Wieren SE (eds) Grazing and conservation management. Dordrecht, Springer, pp 275-320

Wardle DA, Bonner KI, Barker GM, Yeates GW, Nicholson KS, Bardgett RD, Watson RN, Ghani A (1999) Plant removals in 
perennial grassland: vegetation dynamics, decomposers, soil biodiversity, and ecosystem properties. Ecol Monogr 69:535568. doi:10.1890/0012-9615(1999)069[0535:PRIPGV]2.0.CO;2

Wassen MJ, Venterink HO, Lapshina ED, Tanneberger F (2005) Endangered plants persist under phosphorous limitation. Nature 437:547-550. doi:10.1038/nature03950

Watt TA, Gibson CWD (1988) The effect of sheep grazing on seedling establishment and survival in grassland. Vegetatio 78:91-98

Watt TA, Treweek JR, Woolmer FS (1996) An experimental study of the impact of seasonal sheep grazing on formely fertilized grassland. J Veg Sci 7:535-542. doi:10.2307/3236302

Weathers KC, Cadenasso ML, Pickett ST (2001) Forest edges as nutrient and pollutant concentrators: potential synergisms between fragmentation, forest canopies and the atmosphere. Conserv Biol 15:15061514. doi:10.1046/j.1523-1739.2001.01090.x

Webb NR (1998) The traditional management of European heathlands. J Appl Ecol 35:987-990

Weibull A-C, Östman Ö (2003) Species composition in agroecosystems: the effect of landscape, habitat and farm management. Basic Appl Ecol 4:349-361. doi:10.1078/1439-1791-00173
Weibull A-C, Bengtsson J, Nohlgren E (2000) Diversity of butterflies in the agricultural landscape: the role of farming system and landscape heterogeneity. Ecography 23:743-750. doi:10.1111/ j.1600-0587.2000.tb00317.x

Weibull A-C, Östman Ö, Granqvist A (2003) Species richness in agroecosystems: the effect of landscape, habitat and farm management. Biodivers Conserv 12:1335-1355. doi:10.1023/ A: 1023617117780

Weiher E, Keddy P (1999) Assembly rules as general constraints on community composition. In: Weiher E, Keddy P (eds) Assembly rules: perspectives, advances, retreats. Cambridge University Press, Cambridge, pp 251-271

Westoby M (1998) A leaf-height-seed (LHS) plant ecology strategy scheme. Plant Soil 199:213-227. doi:10.1023/A:1004327224729

Zimmergren D (1980) The dynamics of seed banks in an area of sandy soil in southern Sweden. Bot Notiser 133:633-641

Zobel M (1997) The relative role of species pools in determining plant species richness: an alternative explanation of species coexistence? Trends Ecol Evol 12:266-269. doi:10.1016/S0169-5347 (97)01096-3 